\title{
Het informatiesysteem onderwijs-arbeidsmarkt. Onderzoekprogramma 1990/1991
}

Citation for published version (APA):

Researchcentrum voor Onderwijs en Arbeidsmarkt, ROA. (1990). Het informatiesysteem onderwijsarbeidsmarkt. Onderzoekprogramma 1990/1991. Researchcentrum voor Onderwijs en Arbeidsmarkt, Faculteit der Economische Wetenschappen. ROA Reports No. 004

https://doi.org/10.26481/umarep.1990004

Document status and date:

Published: 01/01/1990

DOI:

10.26481/umarep.1990004

Document Version:

Publisher's PDF, also known as Version of record

\section{Please check the document version of this publication:}

- A submitted manuscript is the version of the article upon submission and before peer-review. There can be important differences between the submitted version and the official published version of record.

People interested in the research are advised to contact the author for the final version of the publication, or visit the DOI to the publisher's website.

- The final author version and the galley proof are versions of the publication after peer review.

- The final published version features the final layout of the paper including the volume, issue and page numbers.

Link to publication

\footnotetext{
General rights rights.

- You may freely distribute the URL identifying the publication in the public portal. please follow below link for the End User Agreement:

www.umlib.nl/taverne-license

Take down policy

If you believe that this document breaches copyright please contact us at:

repository@maastrichtuniversity.nl

providing details and we will investigate your claim.
}

Copyright and moral rights for the publications made accessible in the public portal are retained by the authors and/or other copyright owners and it is a condition of accessing publications that users recognise and abide by the legal requirements associated with these

- Users may download and print one copy of any publication from the public portal for the purpose of private study or research.

- You may not further distribute the material or use it for any profit-making activity or commercial gain

If the publication is distributed under the terms of Article $25 \mathrm{fa}$ of the Dutch Copyright Act, indicated by the "Taverne" license above, 


\section{HET INFORMATIESYSTEEM ONDERWIJS-ARBEIDSMARKT}

- onderzoekprogramma 1990/1991 -

ROA-R-1990/4

RESEARCHCENTRUM VOOR ONDERWIJS EN ARBEIDSMARKT

Faculteit der Economische Wetenschappen

Rijksuniversiteit Limburg

Maastricht, juni 1990 


\section{CIP-GEGEVENS}

\section{ROA}

Het informatiesysteem onderwijs-arbeidsmarkt: Onderzoekprogramma 1990/1991/ Researchcentrum voor Onderwijs en Arbeidsmarkt. - Maastricht : Researchcentrum voor Onderwijs en Arbeidsmarkt, Faculteit der Economische Wetenschappen, Rijksuniversiteit Limburg. - Rapport/ Researchcentrum voor Onderwijs en Arbeidsmarkt ; 1990/4)

ISBN 90-5321-039-3

SISO 450.43 UDC $681.324:[371: 331.5\}$

refw. onderwijs en arbeidsmarkt; informatiesysteem 


\section{INHOUDSOPGAVE}

VOORWOORD

1. INLEIDING

2. DE POSITIE VAN HET ROA

3. HET INFORMATIESYSTEEM ONDERWIJS-ARBEIDSMARKT

4. HET ONDERZOEKPROGRAMMA

4.1. Inleiding

4.2. Verdere ontwikkeling van het informatiesysteem onderwijsarbeidsmarkt

4.3. Onderzoekprogramma 1990/1991

BIJLAGE 1: PUBLICATIELIJST ROA

BIJLAGE 2: PERSONELE SAMENSTELLING PER 1 JULI 1990 


\section{CIP-GEGEVENS}

\section{ROA}

Het informatiesysteem onderwijs-arbeidsmarkt: Onderzoekprogramma 1990/1991/ Researchcentrum voor Onderwijs en Arbeidsmarkt. - Maastricht : Researchcentrum voor Onderwijs en Arbeidsmarkt, Faculteit der Economische Wetenschappen, Rijksuniversiteit Limburg. - Rapport/ Researchcentrum voor Onderwijs en Arbeidsmarkt ; 1990/41

ISBN 90-5321-039-3

SISO 450.43 UDC 681.324:[371:331.5]

refw. onderwijs en arbeidsmarkt; informatiesysteem 


\section{VOORWOORD}

Dit programmeringsrapport van het Researchcentrum voor Onderwijs en Arbeidsmarkt (ROA) is het vierde in successie. Deze programmeringsrapporten worden samengesteld in het kader van een meerjarige onderzoekopdracht van het Ministerie van Onderwijs en Wetenschappen voor het ontwikkelen van een informatiesysteem onderwijs-arbeidsmarkt. Dit informatiesysteem moet de (toekomstige) ontwikkelingen op de arbeidsmarkt weergeven en de daarvan afgeleide eisen voor het onderwijs tot uitdrukking brengen. Daarbij moet het te ontwikkelen systeem bruikbare informatie opleveren voor de studie- en beroepskeuzevoorlichting in het voortgezet en het hoger onderwijs.

$\mathrm{Na}$ een voorlopige versie van het informatiesysteem onderwijs-arbeidsmarkt die alleen betrekking had op het universitaire onderwijs, is in de loop van 1989 een versie gereed gekomen die zich uitstrekt over het gehele onderwijs. De informatie die in het ontwikkelde systeem is opgenomen, is te raadplegen via het geautomatiseerde informatiesysteem voor studie- en beroepskeuze I-See! en via het ROA-rapport De arbeidsmarkt naar opleiding en beroep in 1992'.

Door het gereedkomen van de eerste volledige versie van het informatiesysteem is er alle aanleiding dit jaar de titel van het programmeringsrapport te wijzigen in Het informatiesysteem onderwijsarbeidsmarkt, onderzoekprogramma 1990/1991. Ook de opzet van het rapport is enigszins gewijzigd. Alle projecten die nauw verwant zijn aan de ontwikkeling van het informatiesysteem zijn nu bijeengebracht onder het A-deel van het programma. Het B-deel omvat de overige onderzoekprojecten. Het A-deel van het programma omvat nu dus ook alle activiteiten met betrekking tot I-See!. Voor het overige is de systematiek van het rapport niet gewijzigd. Het programma betreft dus de geplande werkzaamheden voor een jaarlijks opschuivende periode van twee jaar. Het voorliggende programmeringsrapport heeft betrekking op de periode 1990/1991.

$\mathrm{Na}$ het verschijnen van het vorige programmeringsrapport is het aantal medewerkers gedaald van negentien naar achttien. Het aantal publicaties is evenwel sterk toegenomen. In 1988 verschenen twee rapporten, drie werkdocumenten en vier overdrukken van artikelen en in 1989 waren dat acht rapporten, drie werkdocumenten en een overdruk. Ter informatie wordt in bijlage 1 een recent overzicht gegeven van de ROA-publicatielijst en wordt in bijlage 2 de huidige personele bezetting van het ROA weergegeven.

prof. dr. J.A.M. Heijke

directeur

1. De Grip, Heijke en Dekker, De arbeidsmarkt naar opleiding en beroep in 1992, ROA-R-1989/8, Maastricht. 


\section{INLEIDING}

Door het gereedkomen van de volledige versie van het informatiesysteem onderwijs-arbeidsmarkt, is een belangrijke mijlpaal bereikt bij de uitvoering van het meerjarige onderzoekproject onderwijs en arbeidsmarkt. De opdracht voor dit project werd medio 1986 verleend door het Ministerie van Onderwijs en Wetenschappen aan het Researchcentrum voor Onderwijs en Arbeidsmarkt. Met dit project ${ }^{2}$ wordt beoogd te voorzien in de behoefte aan een onderzoeksinstituut dat zich op permanente basis bezig houdt met analyses en prognoses van ontwikkelingen op de onderwijsmarkt en de arbeidsmarkt, waarbij:

- beide ontwikkelingen met elkaar in verband worden gebracht;

- getracht wordt het gehele onderwijs en de totale arbeidsmarkt te bestrijken;

- zodanige differentiaties in de gegevens worden aangebracht dat een optimale aansluiting wordt verkregen met de meer kwalitatieve aspecten van de relatie onderwijs-arbeidsmarkt;

- naast het uitvoeren van toegepast onderzoek met name aandacht wordt besteed aan de theoretische onderbouwing daarvan.

Bij de opdrachtverlening in 1986 werd uit een negental onderzoekthema's een voorlopige keuze gemaakt van vijf thema's waarop het project onderwijs en arbeidsmarkt zich zou richten ${ }^{3}$. Deze thema's zijn:

1. De ontwikkeling van de werkgelegenheid naar bedrijfstak, beroep (of functiecategorie) en vereiste kwalificaties.

2. De ontwikkeling van de in- en uitstroom van leerlingen in reguliere en bedrijfs(interne) (beroeps) opleidingen.

3. De discrepanties tussen vraag en aanbod op de arbeidsmarkt, naar kwalificatieniveau en -richting, alsmede de coördinatiemechanismen welke vraag en aanbod op de onderscheiden deelmarkten dichter bij elkaar kunnen brengen.

4. De ontwikkeling van nieuwe datasystemen en -bronnen voor de uitvoering van bovengenoemde onderzoekthema's.

5. De ontwikkeling van classificatiesystemen voor een adequate koppeling van de beschikbare gegevens.

Deze thema's werden verder geconcretiseerd in het verzoek van de opdrachtgever om in elk geval een informatiesysteem onderwijs-arbeidsmarkt te ontwikkelen dat bruikbaar is voor de studie- en beroepskeuzevoorlichting aan leerlingen en studenten in het voortgezet- en het hoger onderwijs. Daarnaast zou het informatiesysteem moeten kunnen bijdragen aan een verbetering van de

2. Zie voor een uitgebreide beschrijving van het project onderwijs en arbeidsmarkt: Heijke, Het Researchcentrum voor Onderwijs en Arbeidsmarkt, ROA-R-1986/1 Maastricht.

3. Vgl. voor een uitvoeriger omschrijving: Heijke, t.a.p., ROA-R-1986/1, blz. 12 e.v. 
capaciteitsplanning in het onderwijs en de benutting van de investeringen in kennis en vaardigheden van de bevolking ter versterking van het economisch potentieel.

Er werd voor gekozen om het informatiesysteem onderwijs-arbeidsmarkt langs twee lijnen te ontwikkelen. De eerste lijn betrof het ontwikkelen van een voorlopig informatiesysteem, op basis van direct beschikbare gegevens en op korte termijn te benutten kennis. De tweede lijn hield in het ontwikkelen en uitvoeren van een programma van activiteiten dat is gericht op de geleidelijke uitbouw en verbetering van het informatiesysteem.

In 1987 kwam de eerste versie van het informatiesysteem gereed ${ }^{4}$. Deze versie beperkte zich tot het universitaire onderwijs. Het informatiesysteem omvatte historische data, prognoses tot 1992 en andere indicatoren betreffende de aansluiting tussen het universitaire onderwijs en de arbeidsmarkt. In 1988 werden deze gegevens aangevuld, geactualiseerd en waar nodig gecorrigeerd ${ }^{5}$.

De keuze voor het universitaire onderwijs vloeide voort uit het ontstane samenwerkingsverband met het I-See! project. Dit project houdt de ontwikkeling in van een geautomatiseerd studie- en beroepskeuzesysteem. I-See! werd opgebouwd uit drie modules: een opleidingenmodule, een beroepenmodule en een arbeidsmarktmodule. Het ROA leverde de gegevens voor de arbeidsmarktmodule. De pilotfase van I-See! beperkte zich tot het universitaire onderwijs. Voor een goede afstemming van het project onderwijs en arbeidsmarkt en de ontwikkeling van I-See! was het derhalve doelmatig ook de eerste versie van het informatiesysteem onderwijs-arbeidsmarkt te beperken tot het universitaire onderwijs.

Na de pilotfase werd I-See! verbreed tot alle opleidingen. Gelijktijdig werd door het ROA ook het informatiesysteem onderwijs-arbeidsmarkt uitgebreid tot het gehele voortgezet en hoger onderwijs. Eind $1989 \mathrm{kwam}$ de nieuwe, verbrede, versie van het informatiesysteem gereed $^{8}$. In het informatiesysteem worden 23 bedrijfstakken, 79 beroepsklassen en 53 opleidingstypen onderscheiden. De voortzetting van het samenwerkingsverband met het I-See!-project leidde er toe dat de gegevens van het ROA-informatiesysteem onderwijs-arbeidsmarkt zijn opgenomen in het thans

4. Vgl. voor een samenvatting en wetenschappelijke verantwoording: De Grip, Heijke, Dekker en Groot, De arbeidsmarkt naar beroep in 1992 en de positie van academici daarbinnen, ROA-W1987/1, Maastricht. En voor de volledige versie: De Grip, Heijke, Dekker, Groot en Vos, De arbeidsmarktperspectieven van studierichtingen in het wetenschappelijk onderwijs 1992, Arbeidsmarktmodule I-SEE! project, ROA-R-1987/3.

5. De Grip, Heijke, Van Dam, Dekker en Wieling, Aanvulling arbeidsmarktmodule I-SEE! project (wetenschappelijk onderwijs), ROA-R-1988/2, Maastricht.

6. De Grip, Heijke en Dekker, De arbeidsmarkt naar opleiding en beroep in 1992, ROA-R-1989/8, Maastricht. 
in exploitatie genomen 1-See!-produkt ${ }^{7}$. Behalve de door het ROA verstrekte arbeidsmarktgegevens, bevat de huidige versie van I-See! gegevens over circa 30.000 opleidingen en 1.000 beroepen. De gegevens van I-See! zijn vastgelegd op een CD-ROM, die recentelijk via een abonnementensysteem op de markt is gebracht. De exploitatie van I-See! is in handen van het Landelijk Dienstverlenend Centrum (LDC) i.o. te 's-Gravenhage. De distributie van I-See! wordt verzorgd door NBLC-Systemen. Het is de bedoeling om de gegevens minimaal één keer per jaar te actualiseren.

Met het gereedkomen van de volledige versie van het ROA-informatiesysteem is weliswaar een mijlpaal bereikt, maar bepaald nog geen eindstation. Op dit moment wordt het informatiesysteem nog voornamelijk toegepast in het kader van de studie- en beroepskeuzevoorlichting. De potentiële gebruiksmogelijkheden van het systeem zijn echter veel groter. In de komende programmeringsperiode zullen vier projecten worden opgestart die de toepassingsmogelijkheden van het systeem moeten verbreden.

Het eerste project betreft de realisering van het voornemen elke twee jaar een voor beleidsinstanties informatief rapport uit te brengen met nieuwe statistische data, indicatoren en prognoses betreffende de aansluiting van het onderwijs op de arbeidsmarkt. Het tweede project betreft de regionalisering van het informatiesysteem. Het derde project beoogt een uitbreiding van het informatiesysteem met prognoses van de toekomstige scholingsbehoeften. In het vierde project zullen gegevens uit het informatiesysteem worden toegespitst op vrouwen als een specifieke doelgroep van het beleid dat is gericht op een betere aansluiting van het onderwijs op de arbeidsmarkt.

Naast de uitvoering van bovenstaande nieuwe projecten is een belangrijke taak voor de komende periode de voortdurende actualisering van het systeem met nieuwe statistische basisgegevens en daarop geënte indicatoren en prognoses. Daarnaast wordt gewerkt aan de verdere uitbouw en verbetering van het informatiesysteem. Hierbij zijn onder meer de volgende activiteiten gepland:

- het verbeteren van de prognosemodellen en de daarbij gebruikte econometrische schattingstechnieken;

- het ontwikkelen van nieuwe bronnen van statistische informatie over de arbeidsmarktpositie van schoolverlaters van het voortgezet onderwijs en afgestudeerden van het hoger onderwijs;

- het internationaliseren van het informatiesysteem;

- het ontwikkelen van nieuwe indicatoren voor de aansluiting tussen het onderwijs en de arbeidsmarkt;

- het onderscheiden van startfuncties en loopbaanpatronen;

- het ontwikkelen van een evaluatieprocedure gericht op de verdere verbetering van het informatiesysteem.

7. De Grip, Heijke, Dekker, Beekman en Peeters, De arbeidsmarktperspectieven van beroepsklassen en opleidingstypen in 1992, rapportage I-SEE!, ROA-R-1989/7, Maastricht. 
Elk jaar wordt door het ROA een programmeringsrapport uitgebracht. De onderzoekactiviteiten met betrekking tot het informatiesysteem onderwijs-arbeidsmarkt vervullen daarin een centrale rol. In het rapport wordt een volledig overzicht gegeven van de activiteiten die door het ROA worden ondernomen langs bovengenoemde ontwikkelingslijnen van het informatiesysteem. Daarnaast wordt een overzicht gegeven van de onderzoekprojecten die in meer of mindere mate los van het informatiesysteem onderwijs-arbeidsmarkt worden uitgevoerd.

Het programma beslaat een elk jaar opschuivende periode van twee jaar, waarbij voor het tweede jaar slechts een voorlopige indicatie van het onderzoekprogramma wordt gegeven. Het onderhavige rapport vormt het vierde programmeringsrapport en heeft betrekking op de periode $1990 / 1991^{8}$. Omdat nu een volledige versie van het informatiesysteem onderwijs-arbeidsmarkt is gereedgekomen, is de titel van het programmeringsrapport gewijzigd in Het informatiesysteem onderwijsarbeidsmarkt.

Dit programmeringsrapport is nagenoeg op dezelfde wijze opgezet als het vorige. In hoofdstuk 2 wordt de positie van het ROA geschetst, tussen aan de ene kant de instellingen die statistische basisgegevens en basisprognoses genereren en aan de andere kant de gebruikers van de door het ROA te verschaffen informatie over de arbeidsmarktperspectieven van opleidingen. In hoofdstuk 3 wordt een beeld geschetst van de huidige versie van het informatiesysteem onderwijs-arbeidsmarkt. In hoofdstuk 4 wordt ingegaan op het geplande activiteitenprogramma voor de periode 1990/1991. Het activiteitenprogramma bestaat uit een A-deel, dat betrekking heeft op het informatiesysteem onderwijs-arbeidsmarkt, en een B-deel, dat het overige onderzoek betreft. In afwijking van het vorige programmeringsrapport omvat het A-deel ditmaal ook de onderzoekactiviteiten met betrekking tot 1 See!.

8. De vorige programmeringsrapporten zijn: Naar een informatiesysteem onderwijs-arbeidsmarkt, onderzoekprogramma 1987/1988, ROA-R-1987/2, Maastricht; idem, onderzoekprogramma 1988/1989, ROA-R-1988/1; idem, onderzoekprogramma 1989/1990, ROA-R-1989/1. 


\section{DE POSITIE VAN HET ROA}

De positie van het ROA kan worden toegelicht aan de hand van schema 1 . Het bovenste deel van het schema heeft betrekking op de gegevens waarop het ROA-informatiesysteem is gebaseerd. Een belangrijke basis wordt gevormd door de statistische gegevens van het Centraal Bureau voor de Statistiek (CBS) over de aantallen werkenden naar bedrijfstak, beroep, opleiding, leeftijd, geslacht en arbeidsduur en over de aantallen leerlingen en studenten in het onderwijs. Met behulp van deze gegevens worden de modellen geschat waarmee de ontwikkelingen op de arbeidsmarkt en die in het onderwijs voor de toekomst worden geprognosticeerd. Uit deze gegevens worden ook de indicatoren berekend die een beeld geven van de werkgelegenheidsrisico's luitwijkmogelijkheden, conjunctuurfluctuaties) die aan de keuze voor een bepaalde opleiding of aan het uitoefenen van de verschillende beroepen en functies zijn verbonden.

Met het CBS is in de loop van 1990 een overeenkomst gesloten die het voor het ROA mogelijk maakt micro-databestanden bij het $C B S$ te raadplegen en daaruit naar eigen inzichten gegroepeerde gegevens samen te stellen. Mede in ruil hiervoor zal het ROA analyses van de opleidingsstructuren van beroepen aan het CBS ter beschikking stellen die een steunpunt kunnen bieden voor de verdere ontwikkeling van de beroepenclassificatie van het $\mathrm{CBS}^{9}$.

Er wordt getracht, naast de databestanden van het CBS, ook andere bronnen van statistische gegevens aan te boren, die een nauwkeuriger beeld geven van bepaalde onderdelen van de arbeidsmarkt of het onderwijs. Ten aanzien van het onderwijs kunnen worden genoemd de integrale leerlingentellingen van het Ministerie van Onderwijs en Wetenschappen en de gegevens uit de IBOenquête van het LDC i.o. Verder wordt door het ROA deels in samenwerking met anderen, gewerkt aan het beschikbaar krijgen van gegevens over de uitstroom uit het onderwijs, met name de arbeidsmarktbestemming van schoolverlaters uit het voortgezet onderwijs en van afgestudeerden van het hoger onderwijs. Voor het continu waarnemen van de bestemming van de schoolverlaters is de zogenaamde RUBS-enquête ontwikkeld. Deze enquête is ontwikkeld en in het kader van een pilotproject, getest door een projectteam van medewerkers van enkele COA's, de LCAS, het RION en het ROA.

Het ROA was belast met de coördinatie van het project en de samenstelling van het eindrapport van de experimentele fase van de RUBS-enquête ${ }^{10}$. Het rapport is aangeboden aan de opdrachtgevende

9. Vgl. voor reeds uitgevoerde analyses op dit punt: De Grip, Groot and Heijke, Clustering Occupational Classes by Educational Structure, ROA-W-1987/2E, Maastricht en De Grip, Groot and Heijke, Defining Occupational Groupings by Educational Structure, Environment and Planning $A$, (verschijnt binnenkort).

10. De Grip en Van Dam, Evaluatie van de RUBS-schoolverlatersenquête 1989, ROA-R-1990/2, Maastricht. 
icro - economi-

e en bedrijfssec-

lor prognoses

$\mathrm{CPB}$

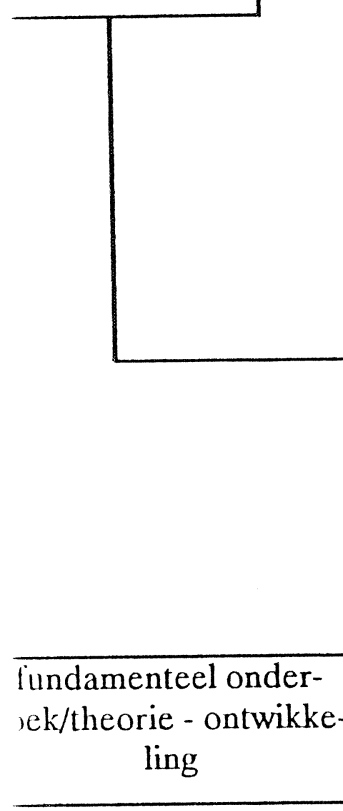

\begin{tabular}{|c|}
\hline onderwijsprognoses \\
CPB, Taakgroep \\
Studentenramin- \\
gen, ROA
\end{tabular}

gen, ROA

\section{bronnen van prog- \\ nosegegevens op \\ deelmarktniveau}

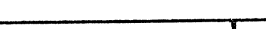

ROA

statistisch basisma-

teriaal

CBS andere bronnen van statistisch basismateriaal
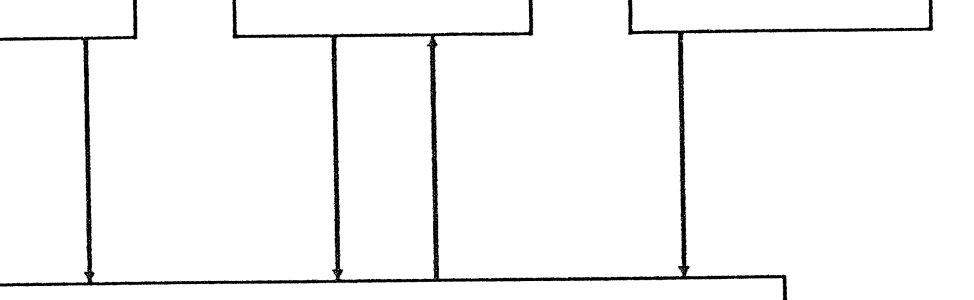

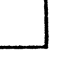
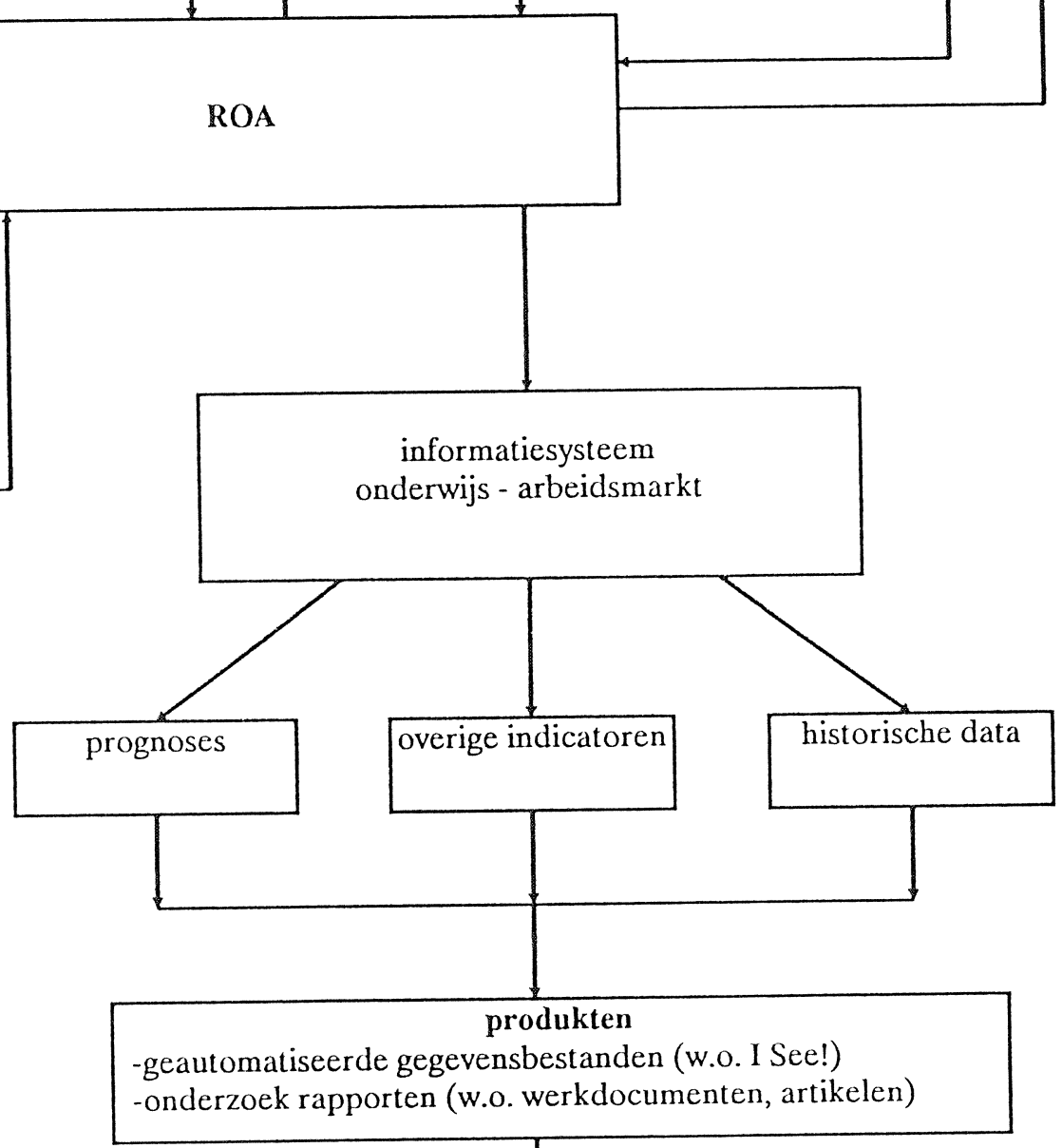

-schooldekanen

-studie- en beroepskeuze adviseurs

-onderwijsinstellingen

-ministeries

-GAB's

-bedrijfsleven

\section{beleidsvelden:}

-studie- en beroepskeuze

-capaciteitsplanning onderwijs

-curriculumplanning onderwijs

-economisch structuur- en technologiebeleid

-om-, her- en bijscholing

-personeelsplanning bedrijven en instellingen 
Ministeries van Sociale Zaken en Werkgelegenheid en Onderwijs en Wetenschappen.

Ook voor het monitoren van de bestemming van de afgestudeerden van de universiteiten is een methodiek ontwikkeld. Deze zogenaamde arbeidsmarktscanner is door het ROA ontwikkeld in opdracht van het Ministerie van Onderwijs en Wetenschappen. Het desbetreffende rapport is aangeboden aan alle Nederlandse universiteiten. De arbeidsmarktscanner wordt thans toegepast aan de Rijksuniversiteit Limburg. Daarnaast worden de mogelijkheden nagegaan om de arbeidsmarktscanner bij andere universiteiten en hogescholen toe te passen. Omdat het ROA bij het beschikbaar maken van deze nieuwe bronnen van gegevens een actieve rol speelt of zou kunnen spelen, zijn de desbetreffende pijlen in het schema in twee richtingen getrokken.

Een belangrijk uitgangspunt voor de prognoses van de ontwikkelingen op de arbeidsmarkt wordt gevormd door de toekomstverkenningen van het Centraal Planbureau (CPB). Het betreft hier met name de middellange-termijnprognoses van de macro-economische ontwikkeling en de werkgelegenheid naar bedrijfstak. Daarnaast wordt gebruik gemaakt van middellangetermijnprognoses van de uitstroom uit het onderwijs naar opleidingscategorie. Deze prognoses zijn afkomstig van het $\mathrm{CPB}^{11}$ (Skill), de Taakgroep Studentenramingen (Worsa en Rhobos) en van het ROA zelf.

Ook ten aanzien van de prognosegegevens wordt getracht bronnen aan te boren die een beter en meer gedifferentieerd beeld geven van bepaalde onderdelen van de arbeidsmarkt of het onderwijs. $\mathrm{Er}$ wordt hier met name gedacht aan prognoses op het niveau van het beroepsdomein van bepaalde opleidingscategorieën, zoals de gezondheidszorg en het onderwijs. Het is denkbaar dat het ROA actief wordt betrokken bij het opstellen van dergelijke meer gedifferentieerde prognoses. Door het ROA worden thans verkenningen gemaakt van de toekomstige arbeidsmarkt voor klinisch psychologen en voor onderzoekers/research \& development personeel met een bèta opleidingsachtergrond.

Het is overigens van belang op te merken, dat er momenteel door de overheid naar wordt gestreefd om de prognose-activiteiten op het terrein van het onderwijs en de arbeidsmarkt zo goed mogelijk te coördineren. Het platform dat hiervoor door de overheid in het leven is geroepen is de interdepartementale commissie Onderwijs-Arbeidsmarkt Prognoses (OAP). Het ROA participeert in enkele werkgroepen van deze commissie.

Het informatiesysteem onderwijs-arbeidsmarkt wordt ontwikkeld op basis van toegepast wetenschappelijk onderzoek. Door de inpassing van het ROA in de economische faculteit van de Rijksuniversiteit Limburg wordt bevorderd, dat zo veel mogelijk profijt kan worden getrokken van de

11. Recent is deze activiteit overgeheveld naar het Ministerie van Onderwijs en Wetenschappen. 
resultaten van onderzoek van een meer fundamenteel karakter. Het ROA probeert in aansluiting hierop ook het fundamentele onderzoek binnen de economische faculteit te stimuleren in een richting welke te zijner tijd vruchten zou kunnen afwerpen voor het informatiesysteem onderwijsarbeidsmarkt.

In het onderste gedeelte van schema 1 is aangegeven welke informatie het systeem oplevert, in wat voor vorm deze informatie is gegoten en ten behoeve van welke beleidsvelden de informatie zou kunnen worden benut. Er zijn daarbij drie soorten informatie onderscheiden: historische data, prognosegegevens en overige indicatoren met betrekking tot de aansluiting onderwijs-arbeidsmarkt. De verschafte informatie wordt verstrekt in de vorm van zowel geautomatiseerde gegevensbestanden als onderzoekrapporten, werkdocumenten en (overdrukken van) artikelen. Een geautomatiseerd gegevensbestand zal vooralsnog alleen te raadplegen zijn via het geautomatiseerde studie- en beroepskeuzesysteem I-See!, dat overigens, zoals in hoofdstuk 1 reeds werd opgemerkt meer modules dan alleen de arbeidsmarktmodule omvat. I-See! wordt via een abonnementensyșteem geëxploiteerd door het LDC i.o. De door het ROA uitgebrachte rapporten en nota's zijn daarentegen direct verkrijgbaar bij het ROA. Voor een volledig overzicht van de tot nu toe verschenen publicaties wordt verwezen naar bijlage 1.

De verschafte informatie richt zich thans primair op de studie- en beroepskeuzevoorlichting. De desbetreffende gegevens bieden echter ook goede aanknopingspunten voor de planning van leerlingencapaciteiten en curricula in het onderwijs, het economische structuur -en technologiebeleid ${ }^{12}$, de om-, her- en bijscholing van werkenden en werklozen en de personeelsplanning van bedrijven en instellingen. De potentiële afnemers van de informatie worden gevormd door de instanties die op de genoemde beleidsvelden actief zijn. In het schema worden de volgende instanties genoemd: schooldecanen, studie- en beroepskeuze-adviseurs, onderwijsinstellingen, ministeries, arbeidsbureaus en het bedrijfsleven.

12. Zie De Grip en Nusselder, Technologie-indicatoren met betrekking tot scholing en arbeid, ROA-R$1989 / 4$. 


\section{HET INFORMATIESYSTEEM ONDERWIJS-ARBEIDSMARKT}

In de versie van het informatiesysteem onderwijs-arbeidsmarkt die in 1987 gereed kwam, werden gegevens verstrekt op basis van een indeling van de arbeidsmarkt naar 23 bedrijfstakken, 82 beroepsklassen en 13 clusters van universitaire studierichtingen. Het informatiesysteem omvatte de volgende gegevens:

- Historische data. Ten aanzien van beroepen werden gegevens verstrekt over het aantal werkenden, de leeftijdsopbouw, de gevolgde opleidingen en de bedrijfsklassen waarin men werkzaam is. De gegevens over opleidingen betroffen het aantal werkenden, de beroepsklassen waarin men werkzaam is en de werkloosheid.

- Indicatoren. Voor beroepen werden indicatoren gegeven van de vervangingsbehoefte, de absorptie van jongeren, de branchespreiding en de conjunctuurgevoeligheid. Voor opleidingen werd een indicator gegeven van de spreiding over beroepen (de zgn. uitwijkmogelijkheden).

- Prognoses. De prognoses hadden betrekking op de periode 1985-1992. De prognoses van beroepen leverden gegevens op over de werkgelegenheidsontwikkeling, de vervangingsvraag, de hieruit resulterende vraag naar nieuwkomers en over de vraag naar onderwijsverlaters. De prognoses voor (universitaire) opleidingen hadden betrekking op de werkgelegenheidsontwikkeling, de vervangingsvraag, de hieruit resulterende vraag naar nieuwkomers, de instroom van afgestudeerden en de confrontatie van de vraag naar nieuwkomers en de instroom van afgestudeerden $^{13}$. In 1988 werden deze gegevens aangevuld, geactualiseerd en waar nodig gecorrigeerd ${ }^{14}$.

In 1989 is een geheel nieuwe versie van het informatiesysteem gereedgekomen ${ }^{15}$. Hierbij is het aantal onderscheiden opleidingscategorieën aanzienlijk vergroot. De 13 clusters van universitaire studierichtingen zijn uitgebreid tot 53 opleidingscategorieën, die het gehele voortgezet en hogere onderwijs omvatten. Helaas is het vooralsnog niet mogelijk geweest de prognosetermijn met twee jaar te verlengen tot 1994, wegens het ontbreken van meso-economische middellangetermijnprognoses van het CPB ten tijde van het opstellen van de bovengenoemde ROA-prognoses en het eveneens ontbreken van recente arbeidsmarktinformatie over opleidingen uit de Enquête Beroepsbevolking (EBB), de opvolger van de Arbeidskrachtentelling (AKT).

13. De Grip, Heijke, Dekker, Groot en Vos, t.a.p. ROA-R-1987/3; zie ook: De Grip, Heijke, Dekker en Groot, t.a.p. ROA-W-1987/1, en van dezelfde auteurs, De arbeidsmarkt naar beroep in 1992 en Arbeidsmarktperspectieven van universitaire studierichtingen, in: Economisch Statistische Berichten, resp. 29 juni en 6 juli 1988, blz. 617-622 en blz. 628-631 en 636 .

14. De Grip, Heijke, Van Dam, Dekker en Wieling, t.a.p. ROA-R-1988/2.

15. De Grip, Heijke en Dekker, t.a.p. ROA-R-1989/8, en van dezelfde auteurs, De arbeidsmarkt naar opleiding in 1992, Economisch Statistische Berichten, 9 mei 1990, b/z. 428-432. 
In schema 2 is aangegeven hoe het informatiesysteem onderwijs-arbeidsmarkt dat in 1989 is gereedgekomen er uit ziet. De belangrijkste verschillen met de vorige versie van het systeem ${ }^{16}$ zijn dat er is getracht rekening te houden met enkele factoren die voor de arbeidsmarkt van grote betekenis kunnen zijn, maar in de vorige versie nog niet expliciet of in onvoldoende mate werden onderscheiden. Deze factoren zijn: de stand van de techniek, de conjunctuurfase en de verdringing op de arbeidsmarkt.

Het informatiesysteem dat nu is ontwikkeld kan aan de hand van schema 2 als volgt worden toegelicht. Het bovenste deel van het schema heeft betrekking op de belangrijkste veronderstellingen en extern opgestelde prognoses die ten grondslag liggen aan de arbeidsmarktprognoses van het ROA. Daaronder wordt de globale structuur van het systeem weergegeven. Het systeem is opgebouwd uit drie lagen. De bovenste laag betreft de bedrijfstakgegevens, de middelste laag heeft betrekking op het beroependeel van het informatiesysteem en de onderste laag geeft het opleidingendeel weer.

De veronderstellingen en prognoses die de uitgangspunten vormen voor de arbeidsmarktprognoses van het ROA, zijn ontleend aan het CPB. De desbetreffende gegevens zijn:

- de ontwikkeling per bedrijfstak van de investeringen, de toegevoegde waarde, het arbeidsvolume, de arbeidsduur en de mate van deeltijdarbeid;

- de demografische ontwikkeling en de daaruit afgeleide ontwikkeling van de leerlingenstromen door en uit het onderwijs en de opleidingsstructuur van de potentiele beroepsbevolking;

- de participatiegraad van de bevolking.

Uit de CPB-prognoses van het arbeidsvolume per bedrijfstak wordt door het ROA voor elke bedrijfstak de werkgelegenheid in aantallen personen naar beroep afgeleid. Hierbij wordt gebruik gemaakt van modellen waarin expliciet wordt rekening gehouden met de invloed van de technologie en de conjunctuur op de beroepenstructuur van de werkgelegenheid per bedrijfstak ${ }^{17}$. De technologie wordt gemeten via de variabelen kapitaalintensiteit en het aandeel automatiseringspersoneel per bedrijfstak; de conjunctuur wordt gemeten via de bezettingsgraad van de produktiecapaciteit per bedrijfstak. Deze benadering vormt een belangrijke stap vooruit vergeleken met de eerste versie van het informatiesysteem, waarin de ontwikkeling van de desbetreffende werkgelegenheidsaandelen uitsluitend werd gerelateerd aan het verloop van de tijd of aan de werkgelegenheidsontwikkeling per bedrijfstak.

16. Zie het desbetreffende onderzoekprogramma, ROA-R-1988/1, blz. 10-11. 17. Dekker, De Grip en Heijke, Een verklaring van de beroepenstructuur van bedrijfstakken, ROA-W-
1988/2, Maastricht. 
Ook de prognoses van de werkgelegenheid naar opleiding zijn op een andere manier opgezet ${ }^{18}$. In de vorige versie van het informatiesysteem werd de werkgelegenheid naar opleiding afgeleid van de totale werkgelegenheid naar beroep. Hierbij werden de opleidingsaandelen per beroep, analoog aan bovengenoemde beroepenmodellen, gerelateerd aan het verloop van de tijd of aan de werkgelegenheidsontwikkeling per beroep. In de nieuwe opzet is een aanzienlijk meer verfijnde aanpak gevolgd. De opleidingenstructuur van beroepen wordt nu per bedrijfstak bepaald. Eerst wordt de opleidingsniveaustructuur van het beroep in de bedrijfstak bepaald, rekening houdend met zowel de mogelijkheid van een "upgrading" of "downgrading" van de voor de desbetreffende beroepscategorie vereiste vaardigheden door de technologische ontwikkeling als met de mogelijkheid dat lagere door hogere opleidingsniveaus worden gesubstitueerd c.q. worden verdrongen, op grond van de ontwikkeling van de relatieve aandelen van deze opleidingsniveaus in de potentiële beroepsbevolking. Vervolgens wordt voor elk opleidingsniveau (binnen een beroep in een bedrijfstak) de werkgelegenheidsaandelen van de verschillende opleidingsrichtingen bepaald. Wat het laatste betreft is vooralsnog volstaan met een eenvoudige trendextrapolatie.

De berekening van de verwachte vervangingsvraag naar beroep en naar opleiding is als volgt. Op basis van onder meer de geprognosticeerde participatiegraad van de verschillende leefijdscohorten naar geslacht, het personeelsverloop van de diverse leeftijdscohorten (naar geslacht) in het desbetreffende beroep in het verleden en de leeftijdsstructuur van het aantal werkzame personen naar beroep in het basisjaar van de prognoses, wordt een schatting gemaakt van de toekomstige vervangingsvraag naar beroep over de prognoseperiode. Dit opgeteld bij de geprognosticeerde toe- of afname van het aantal werkzame personen naar beroep levert een raming op van de totale vraag naar nieuwkomers ('job openings') per beroep over de prognoseperiode. De vervangingsvraag naar opleiding wordt berekend door de vervangingsvraag per beroep over de opleidingen te verdelen met behulp van de beschikbare informatie over de opleidingenstructuur van deze beroepen. Door optelling van vervangings- en uitbreidingsvraag per opleiding wordt de totale vraag naar nieuwkomers per opleiding over de prognoseperiode verkregen.

In het beroependeel van het schema staat aangegeven dat de geprognosticeerde vraagontwikkeling naar beroep, samen met de berekende indicatoren van de conjunctuurgevoeligheid en de branchespreiding van de verschillende beroepen, een algehele typering geven van de werkgelegenheidsperspectieven van de diverse beroepen.

In het opleidingendeel van het schema is aangegeven dat tenslotte de geprognosticeerde vraag naar nieuwkomers per opleiding wordt geconfronteerd met de geprognosticeerde uitstroom van afgestudeerden van de desbetreffende opleiding. De uitstroomprognoses zijn ontleend aan de Taakgroep Studentenramingen (voor het hoger onderwijs), het CPB (voor de lagere niveaus) en het 18. Beekman, Dekker, De Grip, en Heijke, Een verklaring van de opleidingenstructuur van beroepen,
ROA-W-1989/3, Maastricht. 
ROA zelf voor de niet door het CPB onderscheiden differentiaties en de niet door het CPB of de Taakgroep Studentenramingen onderscheiden opleidingen. Door het ROA moesten met name prognoses worden gemaakt van de uitstroom uit niet-reguliere opleidingen die van invloed zijn op de kwalificatiestructuur van het arbeidsaanbod. Het gaat hier vooral om het leerlingwezen, de erkende schriftelijke opleidingen en de opleidingen in de gezondheidszorg.

De discrepanties die resulteren uit de confrontatie van de vraag naar nieuwkomers met de uitstroom uit het onderwijs en de berekende indicator van de mate van spreiding van de afgestudeerden in een bepaalde opleiding over de beroepen, geven een algehele kwalitatieve typering van het arbeidsmarktperspectief van de desbetreffende opleiding. 


\section{HET ONDERZOEKPROGRAMMA}

\subsection{Inleiding}

Het jaarlijks uitgebrachte onderzoekprogramma dekt een telkens opschuivende periode van twee jaar Het onderhavige programma heeft betrekking op de periode 1990/1991.

Het programma bestaat, evenals in de voorgaande jaren, uit twee delen. Deel A had voorheen uitsluitend betrekking op het project onderwijs en arbeidsmarkt, maar betreft nu alle onderzoekactiviteiten die direct verbonden zijn aan het informatiesysteem onderwijs-arbeidsmarkt, dus ook de werkzaamheden die in het kader van het I-See!-project worden uitgevoerd. Deel B betreft het overige onderzoek van het ROA.

Het onderzoekprogramma wordt in twee stappen gepresenteerd. Eerst wordt ingegaan op de verdere ontwikkeling van het informatiesysteem onderwijs-arbeidsmarkt (deel A van het programma). Daarna wordt een overzicht gegeven van de programmadelen A en B voor de periode 1990/1991.

\subsection{Verdere ontwikkeling van het informatiesysteem onderwijs-arbeidsmarkt}

De onderzoekactiviteiten van het ROA met betrekking tot het informatiesysteem onderwijsarbeidsmarkt kunnen worden verdeeld in activiteiten gericht op:

- het toepasbaar maken van de huidige inhoud van het informatiesysteem voor de in schema 1 genoemde beleidsvelden;

- het ontwikkelen van nieuwe bronnen van statistische basisgegevens;

- de verdere ontwikkeling van het informatiesysteem;

- het ontwikkelen van een evaluatieprocedure gericht op de verdere verbetering van het

\section{Gebruik van het informatiesysteem}

Een zeer belangrijke toepassing van het informatiesysteem onderwijs-arbeidsmarkt wordt gevormd door de bijdrage van het ROA aan het 1-See!-project. Dit project heeft tot doel om het studie- en beroepskeuzeproces met gerichte informatie te verbeteren. In 1990 wordt de desbetreffende arbeidsmarktmodule verbeterd en waar mogelijk geactualiseerd. Daarbij zullen de prognoses betrekking hebben op de periode 1989-1994.

Het I-See!-project is vooral afgestemd op de gebruikersbehoeften van instellingen voor studie-en beroepskeuze. Daarnaast streeft het ROA naar een meer beleidsgerichte publicatie. Doel van deze 
publicatie is om de relevante ontwikkelingen in de aansluiting tussen onderwijs en arbeidsmarkt in kaart te brengen en de belangrijkste prognoses weer te geven. Onderdeel van een dergelijke publicatie zou kunnen zijn dat bepaalde beleidsterreinen extra worden belicht. Daarbij kan worden gedacht aan specifieke doelgroepen op de arbeidsmarkt (vrouwen, jongeren, e.d.), verschillen naar regio of ontwikkelingen in specifieke opleidingssectoren (middelbaar beroepsonderwijs e.d.).

Het rapport dat werd uitgebracht in het kader van het gereedkomen van de eerste volledige versie van het informatiesysteem onderwijs-arbeidsmarkt, kan als voorloper van deze beleidsgerichte publicatie worden beschouwd ${ }^{19}$. Er zal in 1990 worden getracht een prototype te ontwikkelen van een meer definitieve versie. Het ROA zal zich hierbij onder andere laten inspireren door de meer beleidsgerichte publicaties van het Bureau of Labor Statistics van het US Department of Labor.

De gegevens die in het rapport worden opgenomen, zullen worden ontleend aan de in 1990 ten behoeve van I-See! bij te stellen versie van het informatiesysteem onderwijs-arbeidsmarkt. In 1991 kan dan de definitieve versie van het rapport verschijnen, op basis van de in dat jaar volledig te vernieuwen versie van het informatiesysteem. Wanneer het rapport zijn definitieve vorm heeft verkregen, zal vervolgens elke twee jaar een actualisering plaatsvinden, waarbij de prognoseperiode ook telkens twee jaar zal opschuiven.

De methodologische verantwoording van de arbeidsmarktprognoses en berekende indicatoren zal in het beleidsgerichte rapport slechts globaal en beschrijvend van aard zijn. De uitgebreide wetenschappelijke verantwoording zal, zoals voorheen, voornamelijk plaatsvinden via de reeks ROAwerkdocumenten en gepubliceerde artikelen.

Het informatiesysteem onderwijs-arbeidsmarkt kan een zelfstandige invloed hebben op de dynamische allocatie van vraag en aanbod op de arbeidsmarkt. Het streven is om met een goede informatievoorziening over de arbeidsmarktperspectieven van opleidingen op middellange termijn, de aansluiting tussen vraag en aanbod op de arbeidsmarkt te verbeteren en varkenscycli in de uitstroom uit het onderwijs te dempen. Deze cycli ontstaan wanneer men bij de studiekeuze slechts kan inspelen op de arbeidsmarktsituatie op het moment waarop men aan de studie begint.

Binnen het kader van het onderzoekprogramma worden enkele empirische verkenningen uitgevoerd die meer inzicht geven in de invloed van arbeidsmarktinformatie op het allocatieproces en de dynamiek van de arbeidsmarkt. Een onderzoek naar de rol van arbeidsmarktinformatie bij de studierichtingkeuze in het lager technisch onderwijs is in 1989 gereed gekomen ${ }^{20}$. Uit dit onderzoek

19. De Grip, Heijke en Dekker, t.a.p., ROA-R-1989/8.

20. Borghans, De Grip and Heijke, Labour market information and the choice of vocational specialisation, ROA-W-1990/2E, Maastricht. 
blijkt de relevantie van het varkenscyclusmodel. Tevens blijkt dat de allocatie aanzienlijk verbeterd kan worden door goede prognoses te verschaffen over de toekomstige arbeidsmarktsituatie. Thans wordt de invloed van arbeidsmarktinformatie op de studiekeuzebeslissingen verder onderzocht bij het wetenschappelijk onderwijs, met als verwachte afrondingsdatum voorjaar 1991. Daarna zullen andere onderwijscategorieën volgen.

De gebruikswaarde van het informatiesysteem zal aanzienlijk kunnen toenemen als enkele uitbreidingen kunnen worden gerealiseerd. In de nieuwe programmaperiode zullen enkele uitbreidingsmogelijkheden worden verkend. Verderop zal nader op deze mogelijkheden worden ingegaan.

\section{Nieuwe databronnen}

De belangrijkste bron voor de arbeidsmarktgegevens van het informatiesysteem onderwijsarbeidsmarkt wordt tot nu toe gevormd door de in de periode 1975-1985 elke twee jaar gehouden Arbeidskrachtentellingen (AKT's) van het CBS. Doordat de laatste telling dateert van 1985, wordt het steeds minder verantwoord hierop arbeidsmarktprognoses te baseren. De AKT heeft vanaf 1987 een opvolger gekregen in de vorm van de Enquête Beroepsbevolking (EBB). De onderwijsgegevens uit deze enquête zullen echter pas bruikbaar zijn vanaf 1990. De gegevens van 1990 zullen naar verwachting voorjaar 1991 beschikbaar komen. Wel zal de koppeling van de AKT's aan de EBB's nog de nodige hoofdbrekens kosten. In dit verband is het van belang dat in de loop van 1990 met de EBB de nodige ervaring kan worden opgedaan door de overeenkomst die met het CBS is gesloten over het gebruik van micro-databestanden om daaruit naar eigen inzichten gegroepeerde gegevens samen te stellen. De op deze wijze verkregen gegevens zullen worden gebruikt voor het actualiseren van zowel de prognosemodellen als de in het informatiesysteem opgenomen indicatoren betreffende de aansluiting tussen het onderwijs en de arbeidsmarkt.

Bovengenoemde statistische bronnen zijn gebaseerd op steekproeven van slechts enkele procenten van de (beroeps)bevolking. Dit heeft tot gevolg dat bij publicatie van de resultaten van de uitgevoerde enquêtes geen al te sterke differentiatie mogelijk is naar bijvoorbeeld beroep en opleiding. In het informatiesysteem onderwijs-arbeidsmarkt kunnen daarom per opleidingsniveau gemiddeld slechts 13 studierichtingen worden onderscheiden. Ook laten de gegevens het niet toe loopbaanpatronen te onderscheiden. Om bruikbare arbeidsmarktinformatie ten behoeve van de studieen beroepskeuze te kunnen verschaffen is het noodzakelijk om de opleidingsgegevens verder te differentiëren en loopbaanpatronen in beeld te brengen. Uiteraard zijn er grenzen gesteld aan wat een zinvolle differentiatie van de arbeidsmarktgegevens genoemd kan worden. Deze grenzen worden bepaald door de bestaande segmentatie van de arbeidsmarkt naar deelmarkten. Waar de beschikbare arbeidsmarktgegevens niet volgens deze deelmarkten zijn ingedeeld, en dat is veelal het geval, bestaat toch behoefte aan meer gedesaggregeerde gegevens, om een beter bij de bestaande 
deelmarkten aansluitende indeling te kunnen samenstellen.

Het probleem van onvoldoende gedifferentieerde gegevens kan in belangrijke mate worden opgelost als de scholen voor voortgezet onderwijs en de instellingen voor hoger onderwijs hun schoolverlaters c.q. afgestudeerden op de arbeidsmarkt zouden blijven volgen door middel van regelmatig te herhalen enquêtes. Uiteraard dient daarbij te worden uitgegaan van uniforme definities en classificaties, die aansluiten bij de werkwijze van het CBS. Thans zijn belangrijke stappen in deze richting gezet. Mei 1990 werd het hierboven reeds genoemde pilotproject RUBS afgesloten. Dit project was gericht op de ontwikkeling van een systeem voor het registreren van de "eerste bestemming" op de arbeidsmarkt en de doorstroom naar vervolgonderwijs van de uitstroom van het voortgezet onderwijs $^{21}$. Het ontwikkelde systeem is gebaseerd op een jaarlijks te houden representatieve enquête onder zowel gediplomeerde als niet-gediplomeerde schoolverlaters. Zoals in hoofdstuk 2 reeds werd opgemerkt was het ROA verantwoordelijk voor de landelijke projectcoördinatie. In het door het ROA samengestelde evaluerende eindrapport zijn de bereikte resultaten weergegeven en worden voorstellen gedaan voor de follow-up van het project, naar omvang, inhoud, vorm en organisatorische opzet.

Het RUBS-project zal in zijn definitieve vorm niet het hoger onderwijs omvatten. Het ROA heeft evenwel in opdracht van het Ministerie van Onderwijs en Wetenschappen een systeem ontwikkeld om de arbeidsmarkt van academici in kaart te brengen ${ }^{22}$. Het ontwikkelde monitoringsysteem is gebaseerd op een periodieke enquêtering van afgestudeerden en hun werkgevers. De scanner wordt thans alleen met betrekking tot de afgestudeerden toegepast bij de Rijksuniversiteit Limburg. Ook bij andere universiteiten bestaat belangstelling voor de scanner. Om het systeem te kunnen ontwikkelen tot een voor analyse en prognoses bruikbare database over de arbeidsmarktpositie van universitaire studierichtingen, is een coördinatie van de eventuele universitaire initiatieven op dit terrein dringend gewenst. Deze coördinatiebehoefte betreft vooral de definiëring van begrippen en de gebruikte classificaties ${ }^{23}$.

Het systeem dat voor het wetenschappelijk onderwijs is ontwikkeld, laat zich betrekkelijk eenvoudig omvormen tot een systeem dat ook bruikbaar is voor het hoger beroepsonderwijs. De mogelijkheden daartoe worden op dit moment verkend. Mocht hiertoe worden overgegaan dan ontstaat uiteraard

21. De Grip en Van Dam, t.a.p., ROA-R-1990/2, Maastricht.

22. Van Dam, Heijke en Ramaekers, Ontwerp van een arbeidsmarktscanner voor academici, ROA-R-
1989/3, Maastricht.

23. Vgl. de conclusie van inventariserende studies met betrekking tot respectievelijk het wetenschappelijk onderwijs en het hoger beroepsonderwijs: Van Dam, De Grip en Heijke, Op zoek naar informatiebronnen over de arbeidsmarktpositie van academici, ROA-W-1988/3, Maastricht en Van Dam en Mortier, Inventarisatie van arbeidsmarktonderzoeken onder afgestudeerden van het HBO, ROA-W-1990/1, Maastricht. 
een soortgelijke coördinatiebehoefte als bij het wetenschappelijk onderwijs.

De beschikbare prognoses van de onderwijsuitstroom uit het initiele onderwijs zijn niet gedetailleerd genoeg om een confrontatie met de prognoses van de werkgelegenheid voor nieuwkomers te kunnen maken. De mate van detaillering is vooral onvoldoende ten aanzien van de lagere en middelbare opleidingsniveaus; bovendien ontbreekt het deeltijdonderwijs en het niet-reguliere onderwijs. Deze ontbrekende of onvoldoende gedesaggregeerde gegevens worden door het ROA zelf geschat. De hiervoor te gebruiken statistische basisgegevens zullen in de loop van 1990 worden verbeterd door onder andere gebruik te maken van de Integrale Leerlingtelling en de OVL-Leerlingtelling (met betrekking tot onder andere het leerlingwezen) van het Ministerie van Onderwijs en Wetenschappen en data afkomstig van bepaalde particuliere opleidingsinstituten. Op verzoek van het ROA zijn dit jaar bovendien, bij wijze van experiment, vragen over het aantal studenten/cursisten toegevoegd aan de jaarlijkse enquête van het LDC i.o. onder onderwijsinstellingen. De bovengenoemde databronnen zullen voor zover mogelijk dit jaar worden gebruikt voor de prognoses van de uitstroom uit het onderwijs.

\section{Verdere ontwikkeling van het informatiesysteem}

De verdere ontwikkeling van het informatiesysteem verloopt langs twee lijnen. Enerzijds zijn er enkele projecten die betrekking hebben op de verbetering van de prognosemethodiek, de schattingspocedures of de gebruikte indicatoren en de op basis van de resultaten van deze deelstudies volledige vernieuwing van het informatiesysteem in de loop van 1991. Anderzijds is er een aantal projecten dat beoogt de toepassingsmogelijkheden van het informatiesysteem verder te ontwikkelen en uit te breiden.

In de loop van 1989 is een onderzoek gestart naar een econometrisch meer verantwoorde schatting van de verdeelmodellen die de beroepen- en opleidingenstructuur van de werkgelegenheid weergeven $^{24}$. Bij deze nieuwe schattingen wordt de werkgelegenheid uitgedrukt in arbeidsvolume. Voor de omrekening van de werkgelegenheid in personen naar arbeidsvolume wordt gebruik gemaakt van een door het ROA ontwikkelde schattingsprocedure van de arbeidstijd naar beroep in een sector $^{25}$. De werkzaamheden zijn inmiddels ver gevorderd en kunnen naar verwachting zomer 1990 worden afgerond. De resultaten van de nieuwe schattingen van het beroepenmodel en het opleidingenmodel zullen worden neergelegd in een werkdocument. De nieuwe schattingsmethode zal worden toegepast bij de prognoses van 1991. Verschillende elementen van de nieuwe aanpak zullen echter reeds worden toegepast bij de dit jaar ten behoeve van I-See! op te stellen prognoses.

24. Vgl. voor de oude versies resp. Dekker, De Grip en Heijke, t.a.p., ROA-W-1988/2 en Beekman,
Dekker, De Grip en Heijke, ROA-W-1989/2, Maastricht. 
Een volgende vernieuwing betreft de wijze waarop de vervangingsvraag naar opleiding en beroep wordt geprognosticeerd. Er wordt gewerkt aan een model waarbij in aansluiting op de voorheen gevolgde benadering rekening wordt gehouden met de demografische ontwikkeling en met de conjuncturele en structurele componenten van de participatiegraad van leeftijdsgroepen. In het nieuwe model zal een betere markering worden aangebracht van de scheidingslijn tussen uitbreidingsen vervangingsvraag. De nieuwe benadering houdt in dat onderscheid wordt gemaakt tussen 'vervangingsvraag in ruime zin' en 'vervangingsvraag in enge zin'. De vervangingsvraag in ruime zin meet het personeelsverloop, waarbij de vrijgekomen plaatsen kunnen worden opgevuld door arbeidskrachten die reeds werkzaam zijn buiten de desbetreffende opleidings- of beroepscategorie, of door arbeidskrachten die zich nieuw aanbieden op de arbeidsmarkt. De vervangingsvraag en de uitbreidingsvraag vormen op deze wijze tezamen het totale aantal in de prognoseperiode vrijkomende banen ('job openings'). Zoals opgemerkt zal een deel van de door verloop vrijkomende banen worden opgevuld door arbeidskrachten die voorheen reeds elders werkzaam waren (beroepsmobiliteit e.d.). Door deze banen buiten beschouwing te laten krijgt men een beeld van de vervangingsvraag naar nieuwkomers op de arbeidsmarkt. Dit is de vervangingsbehoefte in enge zin. Winter 1990/1991 zal een werkdocument worden uitgebracht waarin bovenstaande methodiek wordt beschreven. Doordat de voor de nieuwe methodiek benodigde gegevens niet tijdig door het CBS ter beschikking konden worden gesteld, zal bij de in 1990 op te stellen prognoses vooralsnog slechts in beperkte mate gebruik worden gemaakt van de ontwikkelde methodiek.

In 1987 is een werkdocument uitgebracht, waarin met behulp van clustertechnieken een beroepenindeling werd ontwikkeld die qua opleidingsprofiel meer homogene beroepen opleverde dan de tweecijferige beroepencode van het $\mathrm{CBS}^{26}$. Najaar 1990 zal de op basis hiervan ontwikkelde ROAberoepenclassificatie definitief worden gemaakt. De nieuwe indeling zal een uitgangspunt vormen voor de vernieuwing van het informatiesysteem onderwijs-arbeidsmarkt in 1991.

In het vorige programma werd een deelproject onderscheiden dat een inventarisatie inhield van indicatoren voor technologische veranderingen en het ontwikkelen van modellen waarin de relatie tussen deze indicatoren en de beroepenstructuur van bedrijfstakken en de opleidingenstructuur van beroepen per bedrijfstak tot uitdrukking worden gebracht. $\mathrm{Er}$ is echter besloten de thans gebruikte indicatoren voor technologische veranderingen vooralsnog te handhaven, met slechts een geringe aanpassing.

In het informatiesysteem onderwijs-arbeidsmarkt zijn twee indicatoren opgenomen voor de werkgelegenheidsrisico's die aan bepaalde beroepen en opleidingen zijn verbonden. De ene indicator betreft de uitwijkmogelijkheden van opleidingen naar de verschillende beroepen en de andere de conjunctuurgevoeligheid van beroepen. In 1988 werden in een werkdocument enkele nieuwe

26. De Grip, Groot and Heijke, t.a.p., ROA-W-1987/2E. 
indicatoren ontwikkeld, bijvoorbeeld voor de verdringing tussen opleidingsniveaus, de substitutiemogelijkheden tussen opleidingen en de toe- en uittredingsmobiliteit met betrekking tot beroepen $^{27}$. Enkele van deze nieuwe indicatoren zullen worden gekwantificeerd en aan het informatiesysteem worden toegevoegd. Hierbij zal ook worden nagegaan welke mogelijkheden het RUBS-databestand biedt voor het ontwikkelen van nieuwe indicatoren of het verder verbijzonderen van de reeds ontwikkelde indicatoren naar vakrichting. Er wordt naar gestreefd dit deelproject winter $1990 / 1991$ af te ronden.

De indicatoren die hierboven zijn besproken betreffen structuurkenmerken van beroepen en opleidingen. Een indicator die een meer actueel beeld geeft van de kansen met een bepaalde opleiding op de arbeidsmarkt betreft het werkloosheidspercentage naar opleiding. In de huidige versie van het informatiesysteem onderwijs-arbeidsmarkt is dit cijfer reeds opgenomen. De informatiewaarde van het werkloosheidspercentage is echter beperkt. Uit het cijfer kan bijvoorbeeld niet worden afgelezen of het om langdurige werkloosheid gaat of dat het bestand werklozen snel wisselt. Een betere indicator wordt gevormd door de gemiddelde werkloosheidsduur per opleiding. Dit cijfer is echter niet direct voorhanden, maar moet uit de beschikbare werkloosheidsgegevens worden afgeleid. In de loop van 1990 zal hiervoor een model worden ontwikkeld en geschat. De afronding van dit deelproject is gepland op winter 1990/1991.

De arbeidsmarktprognoses die in het informatiesysteem onderwijs-arbeidsmarkt zijn opgenomen, zijn het resultaat van berekeningen met econometrische modellen. De uitkomsten van deze berekeningen zijn vanzelfsprekend behept met ruime onzekerheidsmarges. Daarom worden de exacte modeluitkomsten ten aanzien van de arbeidsmarktperspectieven van opleidingen door het ROA vertaald naar kwalitatieve typeringen die een grotere 'bandbreedte' en derhalve een aanzienlijk grotere betrouwbaarheid hebben. De hierbij tot nu toe gehanteerde klassenindeling is tamelijk ad hoc gekozen. In de nieuwe programmaperiode zal worden getracht de te hanteren kwalitatieve typering van de arbeidsmarktperspectieven van opleidingen beter te onderbouwen. Hetzelfde zal worden gedaan met de diverse kwalitatieve typeringen ten aanzien van historische data en indicatoren. Naar verwachting kan deze activiteit winter 1990/1991 worden afgerond.

Bij het opstellen van de prognoses wordt er naar gestreefd optimaal profijt te trekken van de reeds beschikbare kennis bij andere instellingen. Zo wordt voor de bedrijfstakprognoses en onderwijsuitstroomprognoses gebruik gemaakt van studies van het CPB. Tijdens de nieuwe programmaperiode zullen contacten worden gelegd met andere instellingen die belangrijke informatie kunnen leveren ter ondersteuning van de prognose-activiteiten van het ROA. Hierbij wordt met name gedacht aan instellingen die prognosestudies uitvoeren ten aanzien van de arbeidsmarktperspectieven van specifieke beroepsopleidingen. Voorbeelden hiervan zijn de lerarenopleidingen en de opleidingen

27. De Grip en Heijke, Arbeidsmarktindicatoren: een inventarisatie, ROA-W-1988/1, Maastricht. 
in de gezondheidszorg. De prognose-activiteiten van de te benaderen instellingen moeten uiteraard aan bepaalde kwaliteitseisen voldoen, koppelbaar zijn aan de prognoses van het ROA en met de nodige regelmaat worden herhaald. Er wordt naar gestreefd winter 1990/1991 een verkenning gereed te hebben van de concrete mogelijkheden.

Op basis van bovengenoemde deelstudies zal in 1991 een volledige vernieuwing van het informatiesysteem plaatsvinden. Daarbij zal worden getracht de prognoses betrekking te doen hebben op de periode 1990-1995. Najaar 1991 zullen deze nieuwe prognoses beschikbaar komen.

Naast de genoemde meer methodologische studies worden enkele projecten in uitvoering genomen die een uitbreiding van het informatiesysteem beogen.

Het informatiesysteem onderwijs-arbeidsmarkt geeft vooralsnog alleen inzicht in de perspectieven van opleidingen op de nationale arbeidsmarkt. Veel uitstromers uit het voortgezet onderwijs oriënteren zich echter vooral op de regionale arbeidsmarkt. Ook voor de Regionale Besturen van de Arbeidsvoorziening, de provinciale en gemeentelijke overheden, het regionale bedrijfsleven en de instanties die een intermediërende functie hebben (COA, PVBE, regionale organen leerlingwezen) is regionaal gespecificeerde informatie onontbeerlijk. Daarom is het zinvol na te gaan in hoeverre het informatiesysteem te regionaliseren is voor opleidingen beneden het niveau van het hoger onderwijs. Hierbij zal in het bijzonder worden nagegaan welke aanvullende regionale databestanden beschikbaar zijn en welk regionaal niveau haalbaar is. Deze verkenning zal najaar 1990 gereed komen.

De afgestudeerden van hogere opleidingen zullen zich in toenemende mate oriënteren op de internationale arbeidsmarkt. In het licht van het wegvallen van de grensbarrières in 1992 zullen vooral Europese landen in de belangstelling komen te staan. Voor de lagere opleidingen moet dan in het bijzonder worden gedacht aan de mogelijkheid dat in de grensregio's de arbeidsmarkten zich tot over de landsgrenzen uitstrekken. Teneinde op deze ontwikkelingen te kunnen inspelen zullen internationale contacten worden gelegd die op den duur kurinen leiden tot een verbreding van het informatiesysteem onderwijs-arbeidsmarkt met internationale arbeidsmarktinformatie.

Het informatiesysteem onderwijs-arbeidsmarkt is gericht op het geven van informatie over de arbeidsmarktperspectieven van opleidingen. Deze perspectieven zijn te onderscheiden naar de perspectieven op de middellange termijn en de perspectieven op de lange termijn. In het eerste geval gaat het om de kans op een baan direct na het afsluiten van de opleiding en in het tweede geval om de betekenis van de genoten opleiding voor de latere beroepsloopbaan. De huidige versie van het informatiesysteem richt zich vooral op het middellange-termijn aspect. De rol van het onderwijs bij het verdere arbeidsleven valt niet goed te reconstrueren uit het beschikbare datamateriaal. Hiervoor zijn longitudinale gegevens nodig, terwijl de beschikbare AKT's en EBB slechts transversale gegevensbestanden zijn. Tijdens de nieuwe programmaperiode zal een begin worden gemaakt met het 
opsporen van bruikbare longitudinale gegevensbestanden en het ontwikkelen van methoden om daaruit loopbaanpatronen c.q. mobiliteitstrajecten af te leiden in relatie tot de gevolgde opleidingen. Er zal worden getracht om zomer 1991 een eerste verkenning af te ronden.

Het is de bedoeling dat het nieuwe Centraal Bestuur van de Arbeidsvoorziening en de daaronder resorterende Regionale Besturen van de Arbeidsvoorziening een activerend arbeidsmarktbeleid gaan voeren. Een belangrijk onderdeel van dit beleid zal het scholingsbeleid vormen. Om de richting van dat beleid te kunnen bepalen is informatie nodig over de toekomstige scholingsbehoefte. Ook ten aanzien van het leerlingwezen en de scholing van werkenden in het algemeen, bestaat er grote behoefte aan informatie over de scholingsbehoefte op korte en middellange termijn. Prognoses van de toekomstige scholingsinspanningen zouden bovendien tot een verbetering kunnen leiden van de prognoses van het aanbod van arbeidskrachten naar opleidingstype. Met het oog hierop zal een deelproject worden uitgevoerd waarbij wordt getracht voortbouwend op de gegevens en methodiek van het informatiesysteem onderwijs-arbeidsmarkt een prognose-instrument te ontwikkelen dat indicaties geeft van de omvang van de scholingsbehoefte naar regio, bedrijfstak, beroep en opleiding. In hoeverre ook indicaties van de specifieke aard van de scholingsbehoeften kunnen worden aangegeven vormt nog onderwerp van onderzoek. In eerst instantie zal de aandacht worden gericht op het prognosticeren van ontwikkelingen in het leerlingwezen. Voorjaar 1991 zal een eerste rapportage van dit onderzoek gereedkomen

Hoewel de participatie van vrouwen in het onderwijs aanzienlijk is toegenomen, kiezen zij, waarschijnlijk vanuit traditionele beperkingen van de studiekeuzehorizon, nog vaak voor studierichtingen met ongunstige arbeidsmarktperspectieven. Uit het oogpunt van studiekeuze en emancipatiebeleid is het daarom nuttig informatie te kunnen geven over de relatieve participatie van vrouwen in de verschillende bedrijfstakken, beroepen en opleidingen en de ontwikkelingen daarin. Daarnaast kan gedacht worden aan het in kaart brengen van mogelijkheden om part-time te werken e.d. Naar verwachting zal zomer 1991 een eerste uitbreiding van het informatiesysteem met betrekking tot 'vrouw en werk' gereed kunnen komen.

\section{Ontwikkeling evaluatieprocedure}

Tot op heden zijn het ontwikkelde informatiesysteem en de daarbij gebruikte onderzoekmethodieken slechts op ad hoc basis geëvalueerd. Deze evaluaties hebben telkens de grondslag gevormd voor verbeteringen op specifieke onderdelen van de gehanteerde onderzoekmethodiek of de inhoudelijke vulling van het informatiesysteem. Geleidelijk aan is de behoefte ontstaan de evaluatie op meer structurele wijze te doen plaatsvinden. Deze evaluatie zou betrekking moeten hebben op de gebruikswaarde van het informatiesysteem voor de beoogde doelgroepen, de onderzoeksmethoden waarmee prognoses en indicatoren worden gegenereerd en de plausibiliteit van de gepresenteerde informatie. Met dit doel zal een rapport worden samengesteld waarin wordt aangegeven op welke 
wijze de genoemde aspecten van het informatiesysteem op adequate wijze kunnen worden geëvalueerd. De voorgestelde evaluatieprocedure zal moeten uitgroeien tot een reguliere activiteit in het kader van het P.O.A./I-See! onderzoekprogramma. Vooruitlopend op een dergelijke evaluatieprocedure zullen in het bovengenoemde rapport enkele belangrijke aspecten van de inhoud en totstandkoming van de huidige versie van het informatiesysteem worden geëvalueerd. Het rapport zal winter 1990/1991 gereed komen.

\subsection{Het onderzoekprogramma 1990/1991}

In deze paragraaf zal een overzicht worden gegeven van de geplande onderzoekactiviteiten voor 1990/1991. De projecten die onder deel A vallen worden slechts kort aangeduid, omdat zij in de vorige paragraaf reeds uitvoerig zijn besproken. Voor deze projecten zal worden volstaan met de titel en de geplande datum van afronding. De projecten onder deel B zullen wat uitvoeriger worden omschreven. Dit laatste overzicht zal naast het lopende onderzoek ook enige informatie geven over de onderzoekprojecten die in 1989 of 1990 zijn afgesloten. Naast een omschrijving van het project wordt telkens de opdrachtgever, de reeds gepubliceerde onderzoekrapporten en bij lopende projecten de geplande datum van afronding vermeld.

Deel A: Het informatiesysteem onderwijs-arbeidsmarkt: lopende en geplande projecten.

Gebruik van het informatiesysteem:

Bijdrage aan I-See!: actualisering data en bijstelling prognoses 1989-1994

Afronding: Najaar 1990.

Ontwikkeling prototype beleidsgerichte publicatie onderwijs-arbeidsmarkt.

Afronding: winter 1990/1991 Onderzoek naar de relatie tussen arbeidsmarktinformatie en varkenscycli in het wetenschappelijk
onderwijs.

Afronding: voorjaar 1991

Nieuwe databronnen:

Pilotproject RUBS (zie deel B).

Ontwikkeling arbeidsmarktscanner academici (zie deel B)

Uitbreiding dataverzameling leerlingen. 
Afronding: zomer 1990

Verdere ontwikkeling van het informatiesysteem:

Herschatting beroepen- en opleidingenmodel

Afronding: zomer 1990

Verbetering prognosemodel vervangingsvraag

Afronding: winter 1990/1991

Samenstelling nieuwe beroepenindeling

Afronding: najaar 1990

Berekening nieuwe arbeidsmarktindicatoren voor opleidingen

Afronding: winter 1990/1991

Schatting werkloosheidsduur naar opleiding

Afronding: winter 1990/1991

Kwalitatieve typering arbeidsmarktperspectieven

Afronding: winter 1990/1991

Verkenning koppeling deelmarktprognoses

Afronding: winter 1990/1991

Opstelling nieuwe arbeidsmarktprognoses (1990-1995)

Afronding: najaar 1991

Verkenning regionalisatie informatiesysteem onderwijs-arbeidsmarkt Afronding: najaar 1990

Activiteiten gericht op internationalisatie informatiesysteem onderwijs-arbeidsmarkt Doorlopende activiteit

Verkenning mogelijkheden voor analyse van loopbaanpatronen

Afronding: zomer 1991

Ontwikkeling prognose-instrument scholingsbehoefte Rapportage: voorjaar 1991 
Uitbreiding informatiesysteem onderwijs-arbeidsmarkt met gegevens over arbeidsmarktperspectieven voor vrouwen

Afronding: zomer 1991

\section{Ontwikkeling evaluatieprocedure}

Inhoudelijke evaluatie van enkele belangrijke aspecten van het huidige informatiesysteem en een daaraan gekoppelde opzet voor een meer reguliere evaluatieprocedure.

Afronding: winter 1990/1991

\section{Deel B: Overig ROA-onderzoek}

In 1989/1990 afgesloten projecten:

\section{Technologische ontwikkeling, beroepenstructuur en opleidingsbehoeften}

In het kader van een door het 'Centre for Educational Research and Innovation ' (CERI) van de OECD opgesteld beleidsplan voor een internationaal gecoördineerd onderzoek naar de relatie tussen technologische ontwikkeling en 'human resources' in de dienstensector, is een onderzoekproject voor Nederland uitgevoerd, waarbij het accent lag op de banksector. De uitvoering vond plaats in een samenwerkingsverband van de vakgroepen Algemene Economie en Kwantitatieve Economie van de Rijksuniversiteit Limburg en het ROA. In het onderzoek zijn de directe gevolgen getraceerd van de technologische veranderingen voor de beroepen- en opleidingenstructuur van de werkgelegenheid en is onderzocht op welke wijze op de ontstane scholingsbehoefte is ingespeeld. Daarbij is een onderscheid gemaakt tussen een scholings- en een wervingsbeleid.

\section{Opdrachtgever : Ministerie van Onderwijs en Wetenschappen}

Onderzoekrapporten : P.J.M. Diederen, A. de Grip, L.F.M. Groot, J.A.M. Heijke, R.P.M. Kemp, J. Muysken and G.R. de Wit, Technological Change, Employment and Skill Formation in Dutch Banking, LIB-R-89/003.

P.J.M. Diederen, A. de Grip, L.F.M. Groot, J.A.M. Heijke, R.P.M. Kemp, J. Muysken and G.R. de Wit, Technological Change and Human Resources in the Service Sector: The Case of the Netherlands, LIB-R-89/004.

P.J.M. Diederen, A. de Grip, L.F.M. Groot, J.A.M. Heijke, R.P.M. Kemp, J. Muysken and G.R. de Wit, Technological Change, Employment and Skill Formation in Dutch Banking, LIB-R-89/005. 
Mogelijkheden voor follow-up onderzoek onder afgestudeerden: pilot-studie gezondheidswetenschappen

In deze pilot-studie is een monitoringsysteem gepresenteerd waarmee gedetailleerde gegevens over de arbeidsmarkt voor afgestudeerden van een universitaire studierichting systematisch kunnen worden gegenereerd. Daartoe zijn vragenlijsten ontwikkeld waarmee afgestudeerde academici en (potentiële) werkgevers periodiek kunnen worden benaderd. Ook is stilgestaan bij de organisatievormen waarbinnen een dergelijk onderzoek kan plaatsvinden en de methoden waarmee de voortgebrachte gegevens op toegankelijke wijze kunnen worden gepresenteerd voor de verschillende doelgroepen. De faculteit der Gezondheidswetenschappen van de Rijksuniversiteit Limburg fungeerde als casus aan de hand waarvan het vereiste onderzoekinstrumentarium werd ontwikkeld en beproefd.

Opdrachtgever

: Ministerie van Onderwijs en Wetenschappen

Onderzoekrapport: J.W. van Dam, J.A.M. Heijke en G.W.M. Ramaekers, Ontwerp van een arbeidsmarktscanner voor academici, ROA-R-1989/3.

\section{Projectcoördinatie RUBS}

Het pilot-project "Registratie Uitstroom en Bestemming Schoolverlaters (RUBS)" had als doel het ontwikkelen van een landelijk bruikbaar meetinstrument ten behoeve van de registratie van de uitstroom van schoolverlaters en hun positie op de arbeidsmarkt. De regionale gegevensverzameling en -verwerking is uitgevoerd door de in het onderzoek participerende Contactcentra OnderwijsArbeid (COA's). Het RION te Groningen verzorgde de ontwikkeling van het meetinstrument en de ontwikkeling van de benodigde software. De LCAS is verantwoordelijk geweest voor een deelproject, gericht op het schetsen van de trendmatige ontwikkelingen in de onderwijsuitstroom 1982-1988 en het extrapoleren van deze ontwikkelingen naar de toekomst. Het ROA was verantwoordelijk voor de algehele projectcoördinatie en het secretariaat van het project. Daarnaast heeft het ROA zorg gedragen voor de algehele evaluatieve verslaggeving naar de opdrachtgever toe, waarbij tevens een overzicht is gegeven van de mogelijke gebruiksdoelen en een tweetal voorstellen is gedaan voor een grootschalige voortzetting van het RUBS-project in de toekomst.

Opdrachtgever : Ministerie van Sociale Zaken en Werkgelegenheid en het Ministerie van Onderwijs en Wetenschappen.

Onderzoekrapport : A. de Grip en J.W. van Dam, Evaluatie van de RUBS-schoolverlatersenquete 1989, ROA-R-1990/2. 


\section{Uitstroomonderzoek MBO Midden-Limburg}

Dit onderzoekproject betrof een enquête onder uitstromers van het MBO te Roermond. Het onderzoek strekte zich uit over de gediplomeerde uitstroom van zowel 1987, als 1988 van de MTS, MEAO, MMO-C en ter vergelijking één afdeling van het KMBO. Door middel van de enquête werd getracht een beeld te schetsen van de 'kwalitatieve aansluiting' van deze schoolverlaters op de arbeidsmarkt. De voor de enquête gebruikte vragenlijst sloot aan bij de nationale instrumentontwikkeling en classificatie in het kader van het hierboven genoemde RUBS-project.

Opdrachtgever : Contactcentrum Onderwijs Arbeid (COA) Midden-Limburg

Onderzoekrapport: P.J.E. van de Loo en A. de Grip, De positie en aans/uiting op de arbeidsmarkt van schoolverlaters van het $M B O$ en Kort MBO in Midden-Limburg, ROA-R$1989 / 5$.

Informatiesysteem onderwijs-arbeidsmarkt Haven van Rotterdam (vooronderzoek)

Het ROA heeft de mogelijkheden onderzocht voor de ontwikkeling van een informatiesysteem onderwijs-arbeidsmarkt voor de haven van Rotterdam. In het vooronderzoek worden voorstellen gedaan voor een informatiesysteem dat een representatief beeld zou kunnen verschaffen van de actuele situatie en in het bijzonder ook van de perspectieven voor de toekomst ten aanzien van de aansluiting onderwijs-arbeidsmarkt. Het informatiesysteem zou een inzichtelijk en praktisch hanteerbaar instrument kunnen vormen voor de beleidsbepaling ten aanzien van de kwantitatieve en kwalitatieve aansluiting van het onderwijs op de arbeidsmarkt.

Opdrachtgever : Havenbedrijf der Gemeente Rotterdam

Onderzoekrapport : A. de Grip, J.A.M. Heijke, W. Nusselder en G.W.M. Ramaekers, Naar een informatiesysteem onderwijs-arbeidsmarkt voor de haven van Rotterdam, verslag vooronderzoek, ROA-R-1989/2.

De aans/uiting tussen beroepen en functies en de relatie met scholings- en mobiliteitsprocessen

In deze studie is de relatie onderzocht tussen gevraagde kwalificaties (functies) en aangeboden kwalificaties (beroepen). Daarbij is ook ingegaan op de dynamiek in deze relatie. Er is getracht antwoord te verkrijgen op de volgende drie vragen:

- Welke verschuivingen zijn er opgetreden in de beroepen- en functiestructuur en de daaraan ten grondslag liggende sectorale werkgelegenheidsstructuur; in welke mate heeft dit geleid tot een toeof afname van de onder- of overbenutting van de beroepskwalificaties?

- In hoeverre kunnen arbeidsmarkttheorieën, die relevant zijn in het kader van de aansluitingsproblematiek, een verklaring geven voor het waargenomen scholings- en 
mobiliteitsgedrag?

- Welke scholings- en mobiliteitsprocessen hebben zich voorgedaan en in hoeverre kunnen deze in relatie worden gebracht met de ontwikkelingen in de beroepen- en functiestructuur en de daaruit resulterende aansluitingsproblematiek?

De studie wordt afgesloten met een analitisch model, dat de deelname aan scholing alsmede de mate van mobiliteit van werkenden verklaart uit een aantal bedrijfs-, functie- en persoonlijke kenmerken.

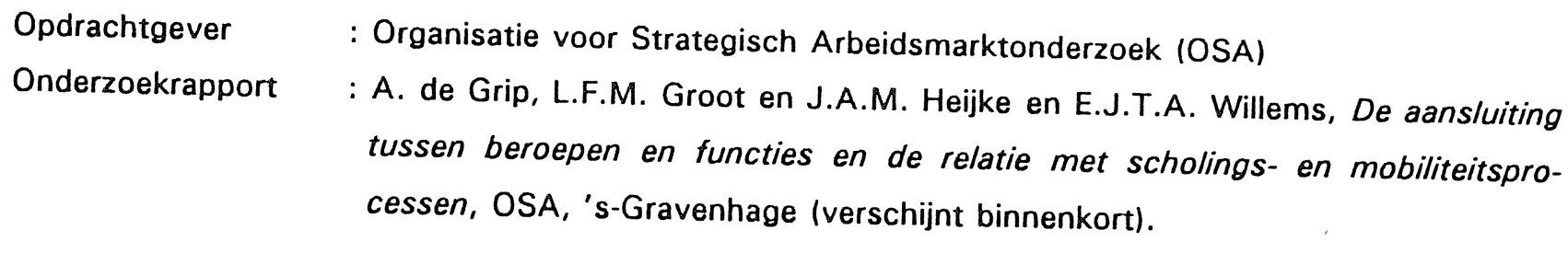

Technologie indicatoren met betrekking tot scholing en arbeid

Dit project betreft de uitvoering van een inventariserend onderzoek naar mogelijke technologieindicatoren met betrekking tot scholing en arbeid die gebruikt kunnen worden in een gegevensbank van technologie-indicatoren en die de mogelijkheid bieden tot het maken van internationale vergelijkingen.

Opdrachtgever : Ministerie van Economische Zaken

Onderzoekrapport : A. de Grip en W.J. Nusselder, Technologie-indicatoren met betrekking tot scholing en arbeid, ROA-R-1989/4. Technology Indicators Referring to Education and Labour, ROA-R-1989/4E.

De betekenis van Europa 1992 voor de migratie van arbeid

Dit project betrof de samenstelling van een pre-advies over de gevolgen van de totstandkoming in 1992 van één ongedeelde markt tussen de landen van de Europese Gemeenschap voor de migratie van arbeid tussen deze landen.

Opdrachtgever : Organisatie voor Strategisch Arbeidsmarktonderzoek (OSA)

Publicatie

: J.A.M. Heijke, Europa, 1992: Start van een migratie 'boom'?, in: H.A. van Stiphout e.a., Werkplaats Europa 1992, pre-adviezen over de gevolgen voor de arbeidsmarkt van de harmonisatie binnen de Europese Gemeenschap, OSAvoorstudie nr. V35, 's-Gravenhage, 1990, blz. 189-200. 
De aans/uiting tussen het hoger onderwijs en de arbeidsmarkt

In deze studie is een overzicht gegeven van de perspectiefvolle ontwikkelingen in het theoretisch en empirisch onderzoek op het terrein van de aansluiting tussen het hoger onderwijs en de arbeidsmarkt. In het rapport wordt aandacht geschonken aan de aard en de oorzaken van de aansluitingsproblematiek en aan de relatie met het onderwijsbeleid en de beleidsevaluatie. Ten slotte worden de voorwaarden die aan de beschikbare data moeten worden gesteld om onderzoek op dit terrein mogelijk te maken geïnventariseerd.

Opdrachtgever : Commissie Beleidsonderzoek Hoger Onderwijs en Wetenschappelijk Onderzoek Onderzoekrapport : L. Borghans, A. de Grip en H. Heijke, De aans/uiting tussen hoger onderwijs en de arbeidsmarkt: een theoretisch kader, ROA-R-1989/6.

Het toekomstige onderzoekerspotentieel: position paper

Ten behoeve van het programma Beleidsstudies Technologie Economie is een position paper geschreven. In het position paper wordt ingegaan op de oorzaken van mogelijke toekomstige tekorten aan onderzoekers. Tevens wordt een voorstel gedaan voor een onderzoeksaanpak.

Opdrachtgever : Ministerie van Economische Zaken

Rapport

: A. de Grip en J.A.M. Heijke, Het toekomstige onderzoekerspotentieel, Position paper voor het programma Beleidsstudies Technologie Economie van het Ministerie van Economische Zaken, 1990.

Lopend onderzoek:

\section{Arbeidsmarktscanner afgestudeerden Rijksuniversiteit Limburg}

Het ROA heeft de opdracht gekregen een systeem voor "follow-up" onderzoek onder afgestudeerden van de Rijksuniversiteit Limburg (RL) op te zetten. Aanleiding hiervoor vormt de grote waarde die de RL hecht aan de afstemming van haar onderwijs op de eisen van de beroepspraktijk en de aansluiting op de mogelijkheden van de arbeidsmarkt. Doel van het op te zetten monitoringsysteem is het systematisch en periodiek beschikbaar komen van informatie over de positie op de arbeidsmarkt van afgestudeerden en het functioneren van alumni in de beroepspraktijk. Het hiervoor benodigde onderzoekinstrumentarium is ontwikkeld in het kader van de eerder genoemde pilotstudie in de gezondheidswetenschappen. Kern van het ontwikkelde project is dat door middel van een jaarlijkse standaardvragenkaart een bestand met basisgegevens van afgestudeerden omtrent hun positie op de arbeidsmarkt wordt ontwikkeld en geactualiseerd. Met een lagere frequentie kunnen meer specifieke 
additionele vragen omtrent de aansluiting van het onderwijs op de eisen van de beroepspraktijk aan alumni worden voorgelegd.

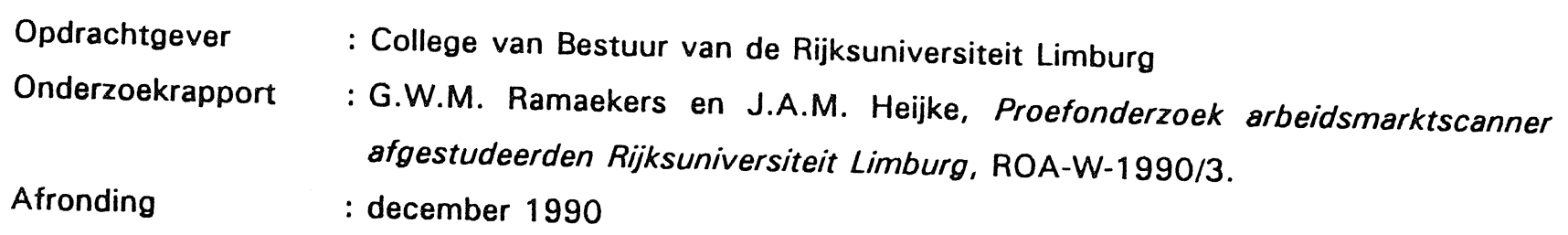

\section{Arbeidsmarkt klinisch psychologen 1995}

Dit project betreft de opstelling van arbeidsmarktprognoses van zowel het aanbod van als de vraag naar klinisch psychologen. De prognoseperiode is 1990-1995. Voor de te ontwikkelen prognosemodellen is gebruik gemaakt van de volgende gegevens: WORSA-studentenprognoses, ledenbestand van het Nederlands Instituut van Psychologen, diverse CBS-data, verschillende onderzoeksrapporten en beleidsnota's, studentenaantallen van relevante faculteiten en studierichtingen.

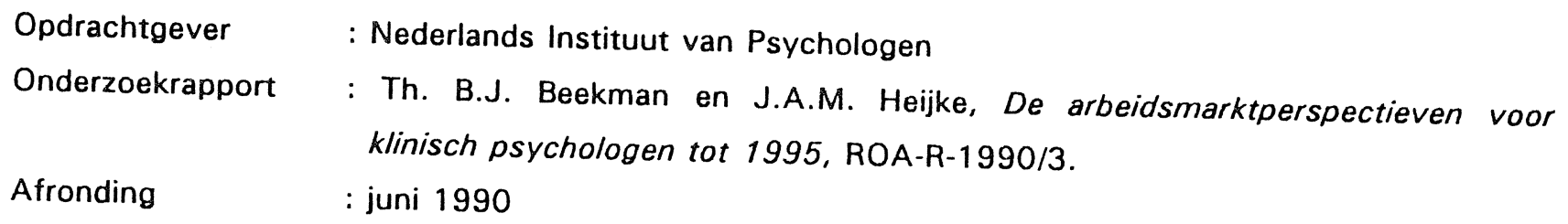

Onderzoek toekomstige schoolverlaters LBO-Limburg

Basis van dit onderzoeksproject is een onlangs gehouden enquête onder vierdejaars leerlingen van het LBO in de provincie Limburg, waarin wordt ingegaan op de motieven van de leerlingen voor hun opleidingkeuze, hun arbeidsmarktverwachtingen en toekomstplannen, waaronder hun (verwachte) bestemming op de arbeidsmarkt. COA-Limburg verzorgt de concrete uitvoering van het onderzoek. Het ROA draagt de zorg voor de algehele supervisie van het onderzoekproject, de benodigde software, e.d.

$\begin{array}{ll}\text { Opdrachtgever } & : \text { COA-Limburg } \\ \text { Afronding } & : \text { oktober } 1990\end{array}$

Het toekomstige onderzoekerspotentieel 2000

In het vervolg op het eerder position paper wordt een prognose-onderzoek verricht naar de toekomstige arbeidsmarktsituatie voor onderzoekers, i.c. research \& developmentpersoneel (bèta en technische wetenschappen). Het onderzoek wordt uitgevoerd in het kader van het 
onderzoekprogramma Beleidsstudies Technologie Economie. In het onderzoek wordt een drietal onderzoeksectoren onderscheiden: universiteiten, onderzoekinstellingen en bedrijfsleven.

Opdrachtgever : Ministerie van Economische Zaken

Afronding : november 1990

Technologie Indicatoren (vervolgonderzoek)

Momenteel wordt gewerkt aan een vervolgstudie op het vorig jaar verrichte onderzoek naar mogelijke technologie-indicatoren met betrekking tot scholing en arbeid. Naast een actualisering van enkele geselecteerde kernindicatoren op basis van internationale databronnen, zal de onderzoeksinspanning ditmaal voor een belangrijk deel worden verlegd naar het benaderen van de nationale statistische bureaus en planningsbureaus e.d.

Opdrachtgever : Ministerie van Economische Zaken

Afronding : september 1990 


\section{BIJLAGE 1 PUBLICATIES ROA}

\section{Rapporten/Reports:}

ROA-R-1986/1

ROA-R-1986/1E

ROA-R-1987/1

ROA-R-1987/2

ROA-R-1987/3

ROA-R-1988/1

ROA-R-1988/2

ROA-R-1989/1

ROA-R-1989/2

ROA-R-1989/3

ROA-R-1989/4

ROA-R-1989/4E

ROA-R-1989/5

ROA-R-1989/6

ROA-R-1989/7

ROA-R-1989/8

ROA-R-1989/8E
J.A.M. Heijke, Het Researchcentrum voor Onderwijs en Arbeidsmarkt.

J.A.M. Heijke, The Research Centre for Education and Labour Market.

A. de Grip, J.A.M. Heijke en L.A. Vos, Inventariserend onderzoek arbeidsmarktmodule I-SEE project.

Naar een informatiesysteem onderwijs-arbeidsmarkt, onderzoekprogramma $1987 / 1988$.

A. de Grip, J.A.M. Heijke, R.J.P. Dekker, L.F.M. Groot en L.A. Vos, De arbeidsmarktperspectieven van studierichtingen in het wetenschappelijk onderwijs 1992, Arbeidsmarktmodule I-SEE project.

Naar een informatiesysteem onderwijs-arbeidsmarkt, onderzoekprogramma 1988/1989.

A. de Grip, J.A.M., Heijke, J.W. van Dam, R.J.P. Dekker en M.H. Wieling, Aanvulling arbeidsmarktmodule I-SEE project (wetenschappelijk onderwijs).

Naar een informatiesysteem onderwijs-arbeidsmarkt, onderzoekprogramma $1988 / 1989$.

A. de Grip, J.A.M. Heijke, W.J. Nusselder en G.W.M. Ramaekers, Naar een informatiesysteem onderwijs-arbeidsmarkt voor de haven van Rotterdam, verslag vooronderzoek.

J.W. van Dam, J.A.M. Heijke en G.W.M. Ramaekers, Ontwerp van een arbeidsmarktscanner voor academici.

A. de Grip en W.J. Nusselder, Technologie-indicatoren met betrekking tot scholing en arbeid.

A. de Grip and W.J. Nusselder, Technology Indicators Referring to Education and Labour.

P.J.E. van de Loo en A. de Grip, De pusitie en aans/uiting op de arbeidsmarkt van schoolverlaters van het $M B O$ en Kort $M B O$.

L. Borghans, A. de Grip en H. Heijke, De aans/uiting tussen het hoger onderwijs en de arbeidsmarkt: een theoretisch kader.

A. de Grip, J.A.M. Heijke, R.J.P. Dekker, Th. B.J. Beekman en H.M.M. Peeters, De arbeidsmarktperspectieven van beroepsklassen en opleidingstypen in 1992: rapportage I-SEE!.

A. de Grip, J.A.M. Heijke en R.J.P. Dekker, De arbeidsmarkt naar opleiding en beroep in 1992.

A. de Grip, J.A.M. Heijke en R.J.P. Dekker, The Labour Market by education and occupation in 1992. 
LIB-R-89/003

LIB-R-89/004

LIB-R-89/005

ROA-R-1990/1

ROA-R-1990/2

ROA-R-1990/3
P.J.M. Diederen, A. de Grip, L.F.M. Groot, J.A.M. Heijke, R.P.M. Kemp, J. Muysken and G.R. de Wit, Technological change, employment and skill formation in Dutch retail.

P.J.M. Diederen, A. de Grip, L.F.M. Groot, J.A.M. Heijke, R.P.M. Kemp, J. Muysken and G.R. de Wit, Technological change and human resources in the service sector: the case of the Netherlands.

P.J.M. Diederen, A. de Grip, L.F.M. Groot, J.A.M. Heijke, R.P.M. Kemp, J. Muysken and G.R. de Wit, Technological change, employment and skill formation in Dutch banking.

W.H. Gijselaers en G.W.M. Ramaekers, De studiekeuze van economiestudenten en hun oordeel over het onderwijs.

A. de Grip en J.W. van Dam, Evaluatie van de RUBS-schoolverlatersenquête.

Th.B.J. Beekman en J.A.M. Heijke, De arbeidsmarktperspectieven voor klinisch psychologen tot 1995.

A. de Grip, L.F.M. Groot, J.A.M. Heijke en E.J.T.A. Willems, De aans/uiting tussen beroepen en functies en de relatie met scholings- en mobiliteitsprocessen, OSA - 's Gravenhage, (verschijnt binnenkort).

\section{Werkdocumenten/Working papers:}

ROA-W-1987/1

ROA-W-1987/1E

ROA-W-1987/2E

ROA-W-1988/1

ROA-W-1988/1E

ROA-W-1988/2

ROA-W-1988/2E

ROA-W-1988/3

ROA-W-1989/1E

ROA-W-1989/2

ROA-W-1989/3
A. de Grip, J.A.M. Heijke, R.J.P. Dekker en L.F.M. Groot, De arbeidsmarkt naar beroep in 1992 en de positie van academici daarbinnen.

A. de Grip, J.A.M. Heijke, R.J.P. Dekker and L.F.M. Groot, Labour Market Prospects for Occupations and Academic Studies in 1992.

A. de Grip, L.F.M. Groot and J.A.M. Heijke, Clustering Occupational Classes by Educational Structure.

A. de Grip en J.A.M. Heijke, Arbeidsmarktindicatoren: een inventarisatie.

A. de Grip and J.A.M. Heijke, Labour Market Indicators: an Inventory.

R.J.P. Dekker, A. de Grip en J.A.M. Heijke, Een verklaring van de beroepenstructuur van bedrijfstakken.

R.J.P. Dekker, A. de Grip and J.A.M. Heijke, An Explanation of the Occupational Structure of Branches of Industry.

J.W. van Dam, A. de Grip en J.A.M. Heijke, Op zoek naar informatiebronnen over de arbeidsmarktpositie van academici.

L. Borghans, Information and the Choice for Schooling.

L.F.M. Groot en J.A.M. Heijke, Een verklaring van arbeidsduur en deeltijdarbeid naar beroep en bedrijfstak.

Th. B.J. Beekman, R.J.P. Dekker, A. de Grip en J.A.M. Heijke, Een verk/aring van de opleidingenstructuur van beroepen. 
ROA-W-1989/3E

ROA-W-1990/1

ROA-W-1990/2E

ROA-W-1990/3
Th. B.J. Beekman, R.J.P. Dekker, A. de Grip and J.A.M. Heijke, An Explanation of the Educational Structure of Occupations.

J.W. van Dam en M.A. Mortier, Inventarisatie van arbeidsmarktonderzoeken onder afgestudeerden van het $H B O$.

L. Borghans, A. de Grip and H. Heijke, Labour-Market Information and the Choice of Vocational Specialisation: a Case Study of the Dutch Junior Secondary Technical Education.

G.W.M. Ramaekers en J.A.M. Heijke, Proefonderzoek arbeidsmarktscanner afgestudeerden Rijksuniversiteit Limburg.

\section{Herdrukken/Reprints:}

nr. 1

nr. 2

nr. 3

nr. 4

nr. 5

nr. 6

nr. 7

nr. 8

nr. 9

nr. 10

nr. 11.
A. de Grip, Causes of Labour Supply and Demand Mismatches in the Dutch Building Trades, in: De Economist, jrg. 135, nr. 2, 1987, pp. 182-200.

J.A.M. Heijke, The Labour Market Position of Migrants in Selected European Receiving Countries, in: The Future of Migration, OECD, Paris, 1987, pp. 170-209.

J.A.M. Heijke, Internationale migratie en bevolkingsstructuur, in: Demografische veranderingen en economische ontwikkelingen. Preadviezen van de Koninklijke Vereniging voor de Staathuishoudkunde 1987, H.E. Stenfert Kroese B.V., Leiden/Antwerpen, 1987, pp. 125-156.

A. de Grip, Winnaars en verliezers op de arbeidsmarkt 1981-1985 in: Tijdschrift voor Arbeidsvraagstukken, jrg. 3, nr. 4, 1987 pp. 61-69.

J.A.M. Heijke, Arbeidsmarktinformatie voor studie en beroepskeuze, in: Dekanoloog, congresbundel, jrg. 25, nr. 1, 1988, pp. 20-22 en 13-14.

J.A.M. Heijke, Arbeidsmarktinformatie en de keuze van studie en beroep, in: Dekanoloog, jaarcongres 1988, jrg. 25, nr. 5/6, pp. 155-160.

A. de Grip. J.A.M. Heijke, R.J.P. Dekker en L.F.M. Groot, "De arbeidsmarkt naar beroep in 1992" en "Arbeidsmarktperspectieven van universitaire studierichtingen", in: Economisch Statistische Berichten, resp. 29 juni en 6 juli 1988, 73e jaargang, nrs. 3662 en 3663.

L.F.M. Groot, J.J. Schippers and J.J. Siegers, The effect of interruptions and part-time work on women's wage rate: a test of the variable- intensity model, in: De Economist, $136 \mathrm{nr} .2$, 1988, pp. 220-238.

A. de Grip, en J.A.M. Heijke, Het flexibiliteitspotentieel van universitaire studierichtingen in: Tijdschrift voor Arbeidsvraagstukken, jrg. 5, 1989 nr. 4, pp. $69 \mathrm{t} / \mathrm{m} 81$.

J.W. van Dam, A. de Grip en J.A.M. Heijke, Huidig follow-up onderzoek levert dikwijls beperkte resultaten, in: Universiteit en Hogeschool, jrg. 36, 1990, nr. 4 , pp. 260-266.

A. de Grip, J.A.M. Heijke en R.J.P. Dekker, De arbeidsmarkt naar opleiding in 1992, in: Economisch Statistische Berichten, 9 mei 1990, 75e jaargang, nr. 3756, pp. 428-432. 


\section{Overige publicaties medewerkers ROA:}

A. de Grip, Onderwijs en arbeidsmarkt: Scholingsdiscrepanties, proefschrift Vrije Universiteit, VUUitgeverij, Amsterdam, 1987.

A. de Grip, Werkgroep Functie-ordening van het Nederlands genootschap voor informatica, Functies in de informatica, typering, plaats, functievereisten, loopbaanmogelijkheden, boekbespreking in: Tijdschrift voor Arbeidsvraagstukken, jrg. 3, nr. 2, 1987, pp. 91-92.

A. de Grip, Arbeidsmarkt als arena, boekbespreking in: Intermediair, jrg. 23, nr. 33, 1987, pp. 57-59.

L.A. Vos, De invloed van arbeidsmarktfactoren op de studiekeuze, doctoraalscriptie Vrije Universiteit, Maastricht, 1987.

F.H.H.C. Stijnen, M.H. Wieling, Arbeidsmarktverwachting en arbeidsmarktpositie van LTS-ers stage-onderzoek in opdracht van COA-Limburg, Maastricht, 1988.

A. de Grip, Scholing en werk: Een analyse van de scholingsproblemen op de arbeidsmarkt en het arbeidsmarktbeleid, SMO-boek, 's-Gravenhage, 1988.

A. de Grip, Commentaar op de methodiek ter berekening van de gewenste instroom van studenten tweedegraads lerarenopleiding algemene vakken, Maastricht, 1989, in opdracht van het Ministerie van Onderwijs en Wetenschappen.

A. de Grip, The Economics of Overeducation: A Comment, in: Economics of Education Review, 1989 , pp. 205-207.

J.W. van Dam, Het imago van de gemeente als werkgever: Verslag van een onderzoek onder HEAOers en HTS-ers en aanbevelingen ter verbetering van de beeldvorming van de gemeente als werkgever, onderzoek in opdracht van de Vereniging van Nederlandse Gemeenten, Den Haag, 1989.

J.A.M. Heijke, Europa, 1992: Start van een migratie 'boom'? in: H.A. van Stiphout e.a., Werkplaats Europa 1992, pre-adviezen over de gevolgen voor de arbeidsmarkt van de harmonisatie binnen de Europese Gemeenschap, OSA-voorstudie nr. V35, 's-Gravenhage, 1990, blz. 189-200.

A. de Grip en L.F.M. Groot, Technologische ontwikkelingen en opleidingseisen in het bankwezen, in: Tijdschrift voor Arbeidsvraagstukken (verschijnt binnenkort).

A. de Grip, L.F.M. Groot and J.A.M. Heijke, Defining Occupational Groupings by Educational Structure, in: Environment and Planning $A$ (verschijnt binnenkort).

L.F.M. Groot and A. de Grip, Technological Change and Skill Formation in the Bank Sector, in: Economics of Education Review (verschijnt binnenkort). 
BIJLAGe 2 PERSONELE SAMENSTELLING ROA PER 1 JULI 1990

\begin{tabular}{|c|c|c|}
\hline Directeur & $:$ & prof. dr. J.A.M. Heijke \\
\hline Hoofdonderzoeker & $:$ & dr. A. de Grip \\
\hline Senior-onderzoeker & $:$ & drs. R.K.W. van der Velden \\
\hline Onderzoekers & $:$ & $\begin{array}{l}\text { drs. Th.B.J. Beekman } \\
\text { drs. H. Berendsen } \\
\text { drs. L. Borghans } \\
\text { drs. J.W. van Dam } \\
\text { drs. R.J.P. Dekker } \\
\text { drs. P.J.E. van de Loo } \\
\text { drs. H.M.M. Peeters } \\
\text { drs. G.W.M. Ramaekers } \\
\text { M.H. Wieling } \\
\text { drs. E.J.T.A. Willems }\end{array}$ \\
\hline Student-assistenten & : & $\begin{array}{l}\text { P.W.T. Ghijsen } \\
\text { J.A. le }\end{array}$ \\
\hline Secretariaat & : & $\begin{array}{l}\text { V.N.H.H. Lonissen-Moonen } \\
\text { L.M.S. Romans } \\
\text { J.M.J.A. Pisters }\end{array}$ \\
\hline Adres & $:$ & $\begin{array}{l}\text { Researchcentrum voor Onderwijs en Arbeidsmarkt } \\
\text { Faculteit der Economische Wetenschappen, } \\
\text { Rijksuniversiteit Limburg } \\
\text { Tongersestraat 53, kamer } 2019 \\
\text { Postbus } 616 \\
6200 \text { MD Maastricht } \\
\text { telefoon: } 043-888120 / 370 \\
\text { telefax : } 043-210999\end{array}$ \\
\hline
\end{tabular}

